\author{
Christian Brzinsky-Fay
}

\title{
Lost in Transition: \\ Labour Market Entry Sequences of School Leavers in Europe
}

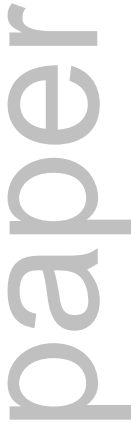

June 2006

ISSN No. 1011-9523

Wissenschaftszentrum Berlin für Sozialforschung (WZB) Social Science Research Center Berlin

Research Area: Employment, Social Structure, and Welfare State

Research Unit:

Labor Market Policy and Employment http://www.wz-berlin.de/ars/ab/ e-mail: brzinsky-fay@wz-berlin.de

Order no.: SP I 2006-111 



\section{ABSTRACT}

Transitional labour markets (TLMs) aim at fostering individual employability over a person's life course under the conditions of flexible labour markets. For TLM policies it is therefore necessary to focus not on single transitions or points of time but on transitional periods. Such a period can contain more than one single transition and add up to an overall sequence type. In particular, the process of labour market entry is characterised by considerable insecurity and varies in duration across individual. From a European perspective, it seems inappropriate to focus on the national level. European policies for tackling youth unemployment should be complementary to certain types of transitional sequences rather than focus on a particular institutional setting.

In the paper I examine sequences of school-to-work transitions in ten European countries by using explorative methods of optimal matching and cluster analysis. The process of labour market entry is observed for the five years following departure from school by examining monthly labour market statuses. The sequences are classified by similarity, and certain sequence types along with their distribution are described. The resulting picture shows strong variation across countries, which can only partly be captured by classic typologies of school-to-work transition regimes. Apart from that, the quality of the coordination process between the educational system and the labour market can be assessed by taking into account indicators derived from the TLM concept, namely, volatility, integrative capability and the degree of risk. 


\section{ZUSAMMENFASSUNG}

Übergangsarbeitsmärkte beabsichtigen, die individuelle Beschäftigungsfähigkeit im Lebensverlauf unter Berücksichtigung flexibler Arbeitsmärkte zu fördern. Entsprechende Politiken können sich daher nicht nur auf einen einzelnen Übergang oder Zeitpunkt konzentrieren, sondern müssen die gesamte Übergangsperiode berücksichtigen. Solche Perioden können mehrere einzelne Übergänge enthalten, die bestimmte Sequenztypen bilden. Insbesondere der Prozess des Einstiegs in den Arbeitsmarkt ist von beträchtlicher Unsicherheit und unterschiedlicher Dauer gekennzeichnet. Aus der europäischen Perspektive erscheint es zudem angebracht, sich nicht auf die nationale Ebene zu beschränken. Europäische Politiken zur Bekämpfung von Jugendarbeitslosigkeit sollten sich eher an bestimmten Übergangssequenztypen orientieren als an institutionellen Konfigurationen.

Das vorliegende Papier untersucht Übergangssequenzen von der Schule in den Beruf in zehn europäischen Ländern unter Verwendung explorativer Methoden wie optimal matching und Clusteranalyse. Der Prozess der Arbeitsmarktintegration wird anhand der monatlichen Arbeitsmarkzustände in den ersten fünf Jahren nach Verlassen der Schule beobachtet. Die Übergangssequenzen werden nach ihrer Ähnlichkeit gruppiert und hinsichtlich ihrer Verteilung beschrieben. Im Ergebnis zeigt sich, dass diese Übergangssequenzen beachtlich zwischen den europäischen Ländern variieren, was nur teilweise durch klassische Typologien von Übergangsregimen erklärt werden kann. Zusätzlich wird die Qualität des Koordinierungsprozesses zwischen Bildungssystem und Arbeitsmarkt anhand von Indikatoren beurteilt, die aus dem Konzept der Übergangsarbeitsmärkte abgeleitet wurden. Hierbei handelt es sich um die Volatilität, die Integrationsfähigkeit und den Risikocharakter von Übergangssequenzen. 


\section{Table of Contents}

1. Introduction........................................................................... 1

2. Theoretical Framework ........................................................... 2

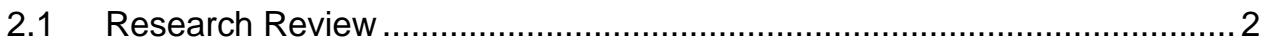

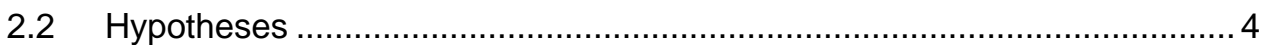

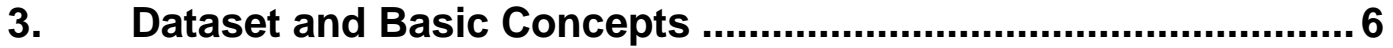

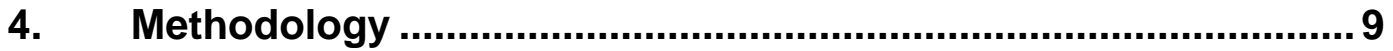

5. Labour Market Entry Sequences ............................................. 13

5.1 Aggregated Characteristics of Labour Market Entry Sequences.............. 13

5.2 Clusters of Labour Market Entry Sequences .................................. 19

5.3 Distribution of Sequence Types across Countries .................................. 25

6. Conclusions and Perspectives.................................................... 28

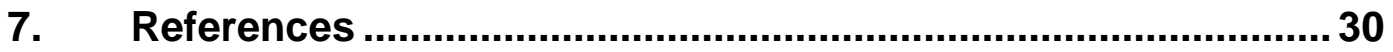





\section{Introduction}

The transition between school and work is a critical period in the life of young people, because their first access to the labour market can have a remarkable effect on their employment history over the entire life course (see Korpi et al. 2003). The school-to-work transition is more than a certain point in time for many reasons. For example, finding a satisfying job can be quite time-consuming, and a number of uncertainties usually emerge during this process, for it is characterised by the simultaneity of other important decisions such as those involving leaving the household and forming a family. Moreover, because the labour market status of young people is not as well protected as that of older people, youth labour markets react more sensitively to socio-economic changes (Gangl 2002: 69). Last but not least is the fact that integration into the labour market is not necessarily completed by taking up one's first job or an apprenticeship. In consideration of these facts, transitional labour market policies that aim to facilitate a good school-to-work transition should not be focussed on one single transition.

Thus, the school-to-work transition must be examined as a period that involves more than one single transition between education and employment or unemployment (Hillmert 2002: 676). Research should focus on the entire sequence of changes in labour market status. Adopting this approach, one is confronted with the problem of complexity, because variation in time and type creates a huge number of theoretically possible sequences. Consequently, one interesting aspect is what these transition sequences look like and how they vary according to different institutional settings. Another important point is that, as a rule, classifications and descriptions of school-to-work transition regimes are made on a national basis. This may lead to inaccurate policy measures that target only major groups or people who are 'typical' for a particular institutional setting. The aim of this paper is to create a classification on the basis of groups containing similar sequences across countries. This approach may help policymakers to adjust their policies to specific target groups on a European level (see McVicar and Anyadike-Danes 2002). Moreover, it is easier to develop policies that change sequences rather than institutions. In line with this approach, the main questions become the following: Are there distinct groups of labour market entry sequences of school leavers? If so, how country-specific are they? And, with respect to integration into the labour market, which types of sequences lead to failure or success?

In order to carry out such a classification, one requires a longitudinal dataset that allows one to identify sequences of labour market statuses and that contains comparable information on European countries. Both requirements are met by the European Community Household Panel (ECHP). Additionally, the comparison 
and classification of sequences requires an explorative method that meets the following demands: first, it should be able to compare a large number of individual transition sequences, and, second, it should be able to group those sequences that are most similar. The techniques of optimal matching and cluster analysis, both of which are used here, satisfy all these demands.

In the next section the theoretical framework and hypotheses about transition sequences are explained in more detail. The data and the methodology are the subject of the following two sections. The empirical results are presented and discussed in the last two sections.

\section{Theoretical Framework}

This section provides an overview of recent research on labour market entry and its institutional preconditions. Hypotheses are then formulated on the basis of this work and applied to the research design.

\section{$2.1 \quad$ Research Review}

There is already a large body of literature on school-to-work transitions at the micro level. There is, however, a crucial gap, which can be filled by using the methodology proposed here. Nearly all of the research work in this field deals with single events such as the transition from one labour market status to the other (e.g. from education to unemployment or employment), their effects and their preconditions (see Scherer 2005). The sequences of school-to-work transitions are rarely examined as entire sequences. Exceptions to this trend are the work of Duncan McVicar and Michael Anyadike-Danes (2002), who examine school-to-work transitions of one cohort of school leavers in Northern Ireland, and the work of Stefani Scherer (2001), who compares patterns of transitional processes in Germany and Great Britain. Both use optimal matching to calculate distances between transition sequences. Apart from that, however, there is no comparison of sequences for more than two countries.

The empirical analysis of labour market sequences in general is a relatively new approach, whose theoretical foundation has been developed through sociological life-course research (see Sackmann and Wingens 2003). Sequences are seen as a concept that connects the macro level, represented by the concept of trajectories, and the micro level, for which the single transition stands. A sequence is defined as 'any life-course movement that includes at least two transitions between states (in a given state space)' (Sackmann and Wingens 2003: 96). Within this concept, a group of sequence types is constructed to capture policy-relevant forms of sequences. The type 'rupture' reflects only a single change with an ab- 
sorbing status at the end. 'Interruption' indicates the continuation of a status after an interlude, whereas 'change' has a different status than the beginning one in between and at the end. The other three statuses consist of a combined form, which, with respect to school-to-work transitions, includes apprenticeship or further education, as both can be seen as a combination of education and employment. In the 'bridge' type, apprenticeship leads from education to employment, whereas in the 'return' type apprenticeship leads back to education. The last type is called 'fusion' and describes the combined state after completion of the two 'pure' states. In the case of school-to-work transitions, the 'fusion' type is finished with (further) education. This sequence typology is used in this paper for the description of sequence clusters.

The concept of transitional labour markets (TLMs) serves as the theoretical background for the analysis of labour market sequences (Schmid 1998, 2002; Schmid and Schömann 2004). Starting from the consideration that globalisation, technological progress and individualisation create an increasing demand for flexibility, and that at the same time social security must be ensured, this concept encourages the take-up of labour market transitions through institutional regulations and policies, which safeguard and motivate employers as well as employees. These institutions are called 'transitional labour markets' and are located at crucial positions on the labour market, such as the transition between employment and the educational system. To ascertain in what way TLMs need to be configured, it is essential to know the empirical shape that transition sequences take. When applying the TLM concept, one differentiates between integrative, maintenance and exclusionary transitions (O'Reilly et al. 2000), and risk management becomes an important issue (Schmid 2006). Thus, the sequences of school-to-work transition are examined in this paper on the basis of indicators derived from the TLM concept. These indicators are volatility, integrative capability and the degree of risk.

From an economic perspective, two types of school-to-work transition regimes are distinguished: internal labour markets (ILM systems) and occupational labour markets (OLM systems) (see Marsden 1999; Shavit and Müller 1998). The former systems are characterised by a lack of clear signals of vocational qualifications: only general education is standardised, and it does not provide occupationally specific skills. This leads to uncertain prospects during the entry period and a relatively low level of occupational segmentation, as labour market allocation relies on work experience that must be gained over time. However, upward mobility in ILM systems is greater than in OLM systems as time goes on. In OLMs, vocational education is highly standardised, and the definition and recognition of qualifications is very clear for employers. Hence, stable employment positions can be reached more quickly and occupational segmentation becomes very strong.

Germany and Great Britain are often viewed as two poles with respect to this coordination process between the educational system and the labour market (see Hillmert 2002; Scherer 2001). Whereas in Germany this process is highly standardised and stratified (see Allmendinger 1989; Shavit and Müller 1998), the co- 
ordination between education and employment in the United Kingdom is comparatively loose (see Hannan et al. 1997). The explanatory power of the ILM/OLM dichotomy will be tested here by means of the findings on transition sequences.

When countries are compared with respect to their institutional configurations that influence welfare as well as labour market processes, Gøsta Esping-Andersen's typology of welfare regimes very often serves as a backbone for analysis (Esping-Andersen 1990, 1999). Because of its universal character, the country groups derived from it are used as a framework for orientation between the countries.

\subsection{Hypotheses}

When I speak of transition sequence clusters that are specific to a particular country, two things must be kept in mind. First, I am speaking about ideal types of sequences; that is, each of the clusters has a more or less significant variation. Second, the presence of a cluster in a particular country only reflects a share of it in a certain size. In practice, one expects that there is more than one type of transition sequence in each country, for each national transition regime permits a few transition types. The different proportions of sequence types reflect the manner in which institutional features shape school-to-work transitions.

H1: Despite a high degree of cross-national variation, all types of transition sequence appear in each country.

It can be expected that the sequence types of the life-course approach mentioned above are not sufficient to describe all the sequence clusters that will be found in the data. However, it is assumed that different institutional settings in combination with corresponding policies shape trajectories for school leavers. For a classic ILM system like that found in the United Kingdom or Ireland, where considerable flows between employment and unemployment are the rule during the labour market entry period (see Detzel and Rubery 2002; Scherer 2001), one can expect that one or more types with frequent transitions between unemployment and employment will be predominant. Furthermore, quick integration into employment presumably will occur in these countries as well. In Germany and Denmark, where a significant number of young people is integrated through the dual system of apprenticeship, the major sequence type after participation in an apprenticeship will lead directly to employment (Detzel and Rubery 2002: 110) or, in other words, to 'lower turbulences at labour market entry' (Scherer 2001: 121).

H2: Countries that have ILM systems will show more changes between labour market statuses than those countries with OLM systems. 
Apart from the empirical questions of what types of transition sequences exist and to what extent they appear in European countries, the more normative question of favourable school-to-work transitions should be raised here as well. This is done by concentrating on particular properties of transition sequences: volatility, integrative capability and the degree of risk.

The volatility of a transition sequence per se can have positive effects or negative effects, depending on the respective statuses of individuals that are undergoing change. In this respect it is argued that the major problem regarding the labour market integration of young people is their lack of work experience and the lack of information about their vocational qualifications. This circumstance inhibits potential employers from hiring inexperienced young people. This risk decreases for both employers and employees when young people participate in further education, an apprenticeship or a combination of the two. Hence, these statuses reflect a comparatively positive volatility, whereas episodes of unemployment and inactivity can be regarded as negative volatility. Several transitions between education, employment and apprenticeship can be expected in countries with a welldeveloped system of further training, such as Denmark, or with an established apprenticeship system, such as Germany. On the other hand, negative volatility can be expected in countries with a low degree of institutional coordination between the educational system and the labour market, such as the United Kingdom and southern European countries.

H3: Countries with well-established initial and/or further training systems will have more positive volatility than will countries without these systems.

The integrative capability of a transition regime depends on how quickly and to what extent young people are integrated into the labour market. Because of the standardised length of the sequences examined here, this property can be assessed by looking only at the share of people who are employed at the end of the observation period. It is to be expected that integrative capability in the southern European countries will be rather low, whereas in the United Kingdom, where the temporal dimension of the integration process is stressed (see Hillmert 2002), the level of integrative capability will be relatively high. For Germany, where the integration process between the educational system and the labour market is highly coordinated, it seems reasonable to expect a relatively high level of integrative capability.

H4: High integrative capability exists in countries where the coordination process between the educational system and the labour market either is structured or emphasises the temporal dimension of labour market integration.

The process of school-to-work transition can be identified as highly risky when it involves many unfavourable episodes and many changes of labour market status and when the probability of being integrated after a certain period of time remains 
relatively low. This situation can be found in particular in countries with a low degree of effective coordination, such as the southern European countries.

H5: Countries with a lower degree of coordination will have a higher share of high-risk transition sequences.

These hypotheses about the characteristics of transition sequences will be examined by taking into account aggregated indicators of single sequences as well as sequence types found in the data.

\section{Dataset and Basic Concepts}

The only available comparative dataset that contains monthly information on labour market status is the European Community Household Panel (ECHP). It is a longitudinal dataset launched by Eurostat, and was collected by the national statistics offices of the member states of the European Union in the years from 1994 to 2001. It includes a large variety of variables covering a number of socioeconomic issues on the individual and the household level. ${ }^{1}$ According to previous research (see Franz et al. 2000; Gangl 2003; Russell and O'Connell 2001), the most important micro-level factors with respect to the labour market integration of young people are age, gender, educational attainment, work experience and duration of unemployment, which are all included in the survey. ${ }^{2}$ Furthermore, it contains monthly calendar information on labour market statuses, which will be analysed by means of optimal matching as well as cluster analysis.

Four countries must be excluded from the analysis on technical grounds. The data for Sweden are only cross-sectional and therefore not to be used for analysing sequences that last longer than one year. Apart from that, there are only missing values in the calendar variables, so that there is no possibility at all to analyse Swedish transition patterns. The latter point is also the case for the Netherlands. Luxembourg and Finland must be excluded as well because there are too few valid cases. In addition, the analysis concentrates on people up to 25 years of age because it not only is the standard age limit in school-to-work literature - both in official reports and in academic research - but it also can be assumed that nearly all young people have left upper secondary school by the age of 20 at the latest. Thus they are included in the sample as well.

To define the beginning of school-to-work transitions would seem to be a straightforward task. One only has to answer the question of whether education stops

1 For further details and discussion, see Peracchi (2002).

2 Work experience and duration of (previous) unemployment can be neglected in this analysis, because the sequences of labour market statuses begin with the first month upon leaving general education. 
after full-time schooling or whether apprenticeships are also part of the educational system. One argument is that an apprenticeship is a form of qualification that is specifically connected to a particular vocation, so it should be viewed as belonging to the sphere of employment, even if participants in apprenticeships spend a large amount of their time at school. ${ }^{3}$ Another argument offered to distinguish apprenticeships from initial education is the crucial role that work experience plays in obtaining a job. Work experience is provided by a job as well as by vocational training such as an apprenticeship, but not by a general education. Furthermore, in order to identify the relevance of apprenticeships for school-towork transitions, it is necessary to examine the weight that they have within the transition period.

The distinction seems more difficult to define when school-to-work transitions are completed. However, setting a limit to the maximum length of the sequences is necessary, for the longer the duration of this period is defined, the less precise is its character as a 'school-to-work transition'. Simple indications for this definition are not sufficient: to let this period end with the beginning of the first job is to ignore later spells of unemployment, inactivity and/or education. This aspect can be important in the presence of discontinuous transition patterns that are characterised by frequent transitions between unemployment and employment. One can attempt to define the end of school-to-work transitions from an aggregate point of view and take the point of time when the employment rate of young people reaches $50 \%$ (see Ryan 1999). In this case, the duration of school-to-work transitions would differ from country to country. Yet constant time periods must be used when assessing quality in terms of the efficiency of school-to-work transitions across countries. Thus, the length of the school-to-work transition is fixed and delimited to five years for the purposes of this research. This definition is to some extent arbitrary, though it does follow other studies in the field (see Scherer 2001). Moreover, it seems necessary to extend the transition period beyond three years, because apprenticeships, which can last up to three years, do not count as education here, and hence are included in the sequences.

The calendar data for labour market status are retrospective and therefore contain information from the year before the surveys were conducted; that is, they include the months from January 1993 to December 2000, amounting to 96 months. If one starts with five-year sequences in every year of the ECHP, then there are four starting points of sequences containing 60 monthly labour market statuses. ${ }^{4}$ All of the sequences were aligned to the left - that is, with the individ-

3 In the ECHP calendar data, apprenticeship spells are defined as 'paid apprenticeships', which excludes them from being counted as measures of active labour market policy.

4 A test with four yearly samples yields the result that there is no significant variation of sequences across time. 
ual's first month not in education, regardless of the year. ${ }^{5}$ Thus, the data sample contains all persons younger than 25 years old who finished general schooling and are observable for five years thereafter. ${ }^{6}$

The recoded categories of the monthly calendar variables for 'labour market status' are 'employed', 'unemployed', 'apprenticeship', 'inactive/household' and 'education'. Employed persons are those who are either self-employed or in dependent employment; inactivity includes housework, family care and military service. Retired young people are excluded, but there are very few cases in each wave. The status 'education' contains university education as well as further education. As discussed above, apprenticeships are not counted as general education, which is a necessary condition to make them visible and to evaluate the effects of apprenticeship systems.

The problem of 'left censoring' can be solved by using other variables as proxies in order to get this information and to keep as many individuals as possible in the analysis. For this purpose, the ECHP provides a variable for people who had not worked before and a variable that contains the age at which the individual stopped his or her education. If this age is smaller than the age of the individual in the first wave of the cohort sample, the person is excluded from the analysis. In a similar vein, the variable that reports the age when the individual started to work can be used to exclude people who have worked before.

Another problem, quite common with analyses of calendar data, regards the lack of information about parallel statuses. For instance, it is not possible to identify from the data those people who are combining work and education. This limitation may represent a considerable reduction of information, but, on the other hand, to cover all possible combinations of two or more statuses at the same time would increase the complexity of the data and the calculation to an extent that is not appropriate for the analysis.

There are three indicators constructed from the sequence data, which capture the volatility, the integrative capability and the degree of risk of the labour market entry sequences. The volatility indicator gives the mathematical fraction of the number of episodes in employment, education and apprenticeship and the number of episodes in unemployment and inactivity. The higher the value of this indicator, the more favourable are sequences with respect to flexibility in the

5 A possible alternative is to create samples from every single year of the survey with people who finished their schooling in the year of reference, but then the number of cases would decrease dramatically.

6 It is assumed that the sample is representative to the same extent as the ECHP is in general. However, the retention ratios with respect to relevant personal characteristics are quite stable across countries (Eurostat 2002), so that comparability is assured. 
particular country. ${ }^{7}$ One advantage of this indicator is that it is independent of the overall level of episode changes, because it only reflects the relation between two kinds of episodes.

The indicator that reflects the integrative capability is created after the types of sequences are worked out and simply gives the added share of those sequence types that for the most part have led to employment after five years. Here, a high value indicates that a national transition regime has a good integrative character.

The same idea lies behind the construction of the risk indicator, in which transition types with a high volatility and a low probability of employment at the end of the period are subsumed. The higher the value of this indicator, the higher is the share of high-risk sequences in a particular country.

\section{Methodology}

The analysis consists of three parts: at first, general characteristics of the transition sequences are described. Second, differences between individual sequences are calculated through the use of optimal matching (OM) ${ }^{8}$ Because this algorithm is only able to calculate distances between the sequences, it requires a further method to group the sequences with similar distances in a second step. This is carried out in a third step through cluster analysis. Finally, the clusters are described and their distribution across countries is examined.

A sequence is defined technically as an ordered listing of items (Maclndoe and Abbott 2004: 387). In the case under consideration here, one monthly labour market status is an item, and a chain of labour market statuses creates a sequence. Within sequences there will be spells made up of a number of identical successive items; for example, three successive months of unemployment is a short spell. Hence, transition sequence clusters are groups of certain empirical successions of labour market statuses in similar sequences that are summarised by an OM algorithm and cluster analysis.

When one analyses transition sequences, the problem of complexity arises. Even if one looks at only ten points of time and has five different labour market statu-

7 Scherer (2001) has suggested taking the share of male part-time work as an indicator of flexibility. Because there is no calendar information on part-time work in the ECHP, this approach is not feasible here.

8 For this part of the analysis the software package TDA is used, which is freeware and available on the following Web site: http://www.stat.ruhr-uni-bochum.de/tda.html. For further information, see Rohwer and Pötter (2005). The author of this paper is currently working together with Ulrich Kohler (at the Social Science Research Center Berlin - WZB) on commands for optimal matching analysis for the software package Stata. It will be available most likely in summer 2006. 
ses, the number of possible combinations is $5^{10}=9,765,625$. In reality, of course, only a small number of all theoretically possible sequences can be found; nevertheless, the problem of complexity is still present. ${ }^{9}$ Moreover, these sequences are nominally scaled and therefore not sortable or easy to aggregate. OM is an explorative method of sequence analysis developed by molecular biologists in order to find similar patterns within DNA. It was first introduced in the social sciences by Andrew Abbott and John Forrest (1986), when they used OM to analyse different figures of ritual dance styles. ${ }^{10}$ Meanwhile, in labour market research there is an increasing number of applications of $\mathrm{OM}$ to life courses and career patterns in general (e.g. Halpin and Chan 1998; Pollock et al. 2002) and with respect to youth in particular (McVicar and Anyadike-Danes 2002; Scherer 2001).

OM is very useful when data have three properties: first, a large number of sequence statuses (items); second, a complex structure of statuses; and, third, a fixed order of items that must be taken into account for analysis. In such a case, confirmatory techniques like event history analysis become inadequate (Halpin 2003: 7): they can deal well with single events or a few events and their effects and preconditions within a sequence of labour market statuses, but because they cannot take into account the entire sequence they ignore valuable information. OM now provides a measure for these confirmatory methods in order to incorporate periodical information into the models.

The OM algorithm works as follows. ${ }^{11}$ First, all sequences are compared pairwise, and distances are calculated. The distance between two sequences is roughly speaking - the sum of steps that one must perform in order to make both sequences equal. In this procedure, which is named 'alignment', there are three operations available: one item can be substituted by another item, an item can be inserted into the first sequence or an item can be deleted from the first sequence. The last two operations are subsumed to so-called indel operations. When transforming one sequence into another, one can use many different combinations of substitution and indel operations. To calculate the distance - that is, the sum of steps of this process - one can simply add together the number of operations. In this case, one substitution of one item by another would be valued with ' 1 ' as well as an indel operation. Now these different operations can be weighted, for one could argue that a substitution has a different meaning than an indel operation does. This weighting of the operations is called 'costs', and depending on the operation they are referred to as 'substitution costs' or 'indel costs'. If the sequences under observation contain more than two statuses, then it might be reasonable to weight the substitution operations as well, so that the substitution of Status 1 by Status 2 receives a different value than the substitution of Status 1 by

9 In this paper the maximum number of theoretically possible sequences follows five different statuses at sixty points of time (months), which amounts to $5^{60}=8.7^{*} 10^{41}$.

10 Abbott and Tsay (2000) give an extensive overview of applications of OM in the social sciences.

11 For a detailed introduction, see MacIndoe and Abbott (2004). 
Status 3. If the sequences are of different lengths, the distances are standardised and the result is a distance matrix that consists of $N^{\star}(N-1) / 2$ values, where $N$ is the number of sequences.

Because there is more than one solution for the alignment of two sequences, the OM algorithm always calculates the minimum distance between two sequences. The distance measure is therefore the minimised combination of substitution and indel costs. The crucial question here is how much a substitution operation costs in relation to an indel operation. The decision about the quantification of these operations is left to the researcher and must be justified by theory. For this reason they are discussed here.

In contrast to indel costs, substitution costs and their weighting (as well as their relation to indel costs) are the subject of enduring discussion (Abbott 2000; Levine 2000; Wu 2000). Recently, most researchers differentiate the substitution costs regarding the state of the sequence element; that is, they either take 'dynamic' substitution costs according to the empirical transition frequencies between these states or 'weight' substitution costs on the basis of theoretical explanations. With respect to labour market statuses, it cannot be convincingly decided which weight a transition between two particular statuses has in relation to other statuses. Therefore, all substitution operations receive the same costs. It seems to be appropriate to fix substitution costs, because it can be assumed that transition frequencies differ greatly across countries. This step would have raised the question of which frequencies should be used for calculating the substitution costs: overall frequencies or country-specific frequencies. Both possibilities seem to be insufficient, because the main matters of interest are the country characteristics. Overall frequencies would lead to a blurring of national differences, whereas country-specific frequencies would critically reduce comparability.

The relation between substitution and indel costs is important because it strongly influences the results of the OM algorithm. Most researchers set up indel costs to equal half of the substitution costs (see Scherer 2001), as this ensures that indel operations are only used by the algorithm to offset different sequence lengths. On the other hand, it is recommended to set indel costs close to 0.1 times the highest substitution costs (Maclndoe and Abbott 2004: 392). To raise the weight of the relative position of the statuses, indel costs are set equal to 1 , whereas substitution costs always will be $2 .{ }^{12}$ If the duration of single spells (e.g. five subsequent months of unemployment) is not as important as the pure sequence of statuses, the calculated distance measures are standardised for reasons of comparability. This can simply be done either by dividing the pairwise distance by the length of the longest sequence in the sample or by reducing all sequences to an

12 For a sensitivity test, different variants of substitution and indel costs were tested, but the results showed only slight differences. 
Table 1: Aggregated characteristics of labour market entry sequences

\begin{tabular}{|c|c|c|c|c|c|c|c|c|c|c|c|c|c|c|c|c|c|}
\hline & & DK & BE & FR & IE & IT & GR & ES & PT & DE & UK & Male & Female & ISCED 0-2 & ISCED 3 & ISCED 4-7 & Total \\
\hline \multirow{5}{*}{$\begin{array}{l}\text { Average } \\
\text { duration } \\
\text { in... }\end{array}$} & education & 19.7 & 26.2 & 12.6 & 17.8 & 11.4 & 7.1 & 14.0 & 12.7 & 5.5 & 5.5 & 11.3 & 11.6 & 3.5 & 9.3 & 20.1 & 11.5 \\
\hline & apprenticeship & 8.4 & 3.1 & 0.1 & 3.5 & 1.5 & 0.3 & 1.3 & 0.1 & 19.7 & 1.4 & 4.1 & 3.1 & 1.5 & 5.2 & 1.9 & 3.6 \\
\hline & employment & 23.3 & 18.3 & 27.6 & 31.0 & 13.8 & 19.2 & 19.8 & 26.6 & 24.3 & 37.8 & 24.4 & 22.8 & 21.6 & 22.7 & 26.5 & 23.6 \\
\hline & unemployment & 4.4 & 9.9 & 9.9 & 5.4 & 25.8 & 20.0 & 17.6 & 10.2 & 5.1 & 8.2 & 12.9 & 15.1 & 19.1 & 15.9 & 7.2 & 14.0 \\
\hline & inactivity & 4.2 & 2.5 & 9.8 & 2.2 & 7.5 & 13.5 & 7.3 & 10.3 & 5.4 & 7.2 & 7.3 & 7.5 & 14.2 & 6.9 & 3.7 & 7.3 \\
\hline \multicolumn{2}{|c|}{$\begin{array}{l}\text { Average number of } \\
\text { different statuses }\end{array}$} & 3.3 & 2.5 & 2.6 & 2.4 & 2.4 & 2.6 & 2.7 & 2.4 & 2.8 & 2.2 & 2.6 & 2.4 & 2.4 & 2.6 & 2.6 & 2.5 \\
\hline \multicolumn{2}{|c|}{$\begin{array}{l}\text { Average number of } \\
\text { episodes (total) }\end{array}$} & 5.8 & 3.7 & 4.8 & 4.9 & 3.7 & 3.7 & 5.0 & 3.8 & 4.2 & 4.0 & 4.6 & 4.0 & 4.4 & 4.0 & 4.6 & 4.3 \\
\hline \multirow{5}{*}{$\begin{array}{l}\text { Average } \\
\text { number of } \\
\text { episodes } \\
\text { in... }\end{array}$} & education & 1.2 & 0.8 & 0.7 & 1.5 & 0.6 & 0.4 & 0.9 & 0.6 & 0.3 & 0.4 & 0.7 & 0.6 & 0.3 & 0.5 & 1.1 & 0.7 \\
\hline & apprenticeship & 0.6 & 0.3 & 0.0 & 0.2 & 0.2 & 0.1 & 0.2 & 0.0 & 0.9 & 0.2 & 0.3 & 0.2 & 0.2 & 0.3 & 0.2 & 0.2 \\
\hline & employment & 2.2 & 1.1 & 1.9 & 2.2 & 0.9 & 1.1 & 1.8 & 1.3 & 1.8 & 1.9 & 1.7 & 1.4 & 1.5 & 1.4 & 1.9 & 1.6 \\
\hline & unemployment & 0.9 & 0.8 & 1.3 & 0.7 & 1.4 & 1.3 & 1.5 & 0.9 & 0.8 & 1.2 & 1.2 & 1.1 & 1.5 & 1.2 & 0.9 & 1.2 \\
\hline & inactivity & 0.9 & 0.8 & 0.9 & 0.3 & 0.6 & 0.9 & 0.7 & 0.9 & 0.4 & 0.4 & 0.7 & 0.6 & 0.9 & 0.6 & 0.5 & 0.6 \\
\hline \multicolumn{2}{|c|}{ Volatility indicator } & 2.1 & 1.4 & 1.2 & 4.0 & 0.8 & 0.7 & 1.3 & 1.1 & 2.6 & 1.5 & 1.4 & 1.3 & 0.8 & 1.2 & 2.4 & 1.4 \\
\hline \multicolumn{2}{|l|}{$\mathrm{N}$} & 52 & 48 & 160 & 164 & 361 & 156 & 206 & 101 & 177 & 208 & 804 & 829 & 500 & 903 & 225 & 1633 \\
\hline
\end{tabular}

Source: ECHP, own calculations. 
equal length (Dijkstra and Taris 1995). For reasons of comparability, all of the sequences under analysis are of the same length, and therefore standardisation is not necessary here.

The OM algorithm generates pairwise distance measures; that is, there is a matrix consisting of numbers for every combination of single sequences. This matrix can be built in a cluster analysis as a dissimilarity measure. In the second step of cluster analysis, the hierarchical fusion algorithm of Ward is used to explore groups of sequences. One of the crucial questions of cluster analysis is to define the ideal number of clusters. For this purpose, some measures are developed to indicate the most distinct level of clustering. Here, the test statistics of CalinskiHarabasz and Duda-Hart as well as contextual arguments are used to define the proper number of clusters. ${ }^{13}$

\section{Labour Market Entry Sequences}

At first, all sequences will be described on an aggregated level with general measures by country, gender and educational level. The detected clusters of sequences are then portrayed and interpreted with respect to country-specific peculiarities.

\subsection{Aggregated Characteristics of Labour Market Entry Sequences}

The first approach to describing labour market statuses is to consider aggregated indicators such as the average duration of statuses, the average number of spells and different statuses, and the average number of spells in particular labour market statuses (see Table 1). The average duration of statuses adds up all months of the same status, regardless of whether they are consecutive or not. Hence, this measure can be taken as an overall frequency of this status. The average number of different statuses reflects a qualitative flexibility in the transition period. A high value denotes that people in this group change this kind of status often. A value of 3 in a particular country indicates that, on average, young people experience three different statuses in the five years after leaving school. The average number of episodes reflects the pure number of spells, not the type of statuses. ${ }^{14}$ It can be taken as a measure for volatility of transition sequences. A low number of episodes is seen as a characteristic of coordinated labour markets. In order to obtain a more precise picture, this volatility measure can be split up by status type and an indicator can be calculated, enabling one to assess the volatility.

13 For a discussion of stopping rules in cluster analysis, see Everitt et al. (2001).

14 The number of status changes (not shown here) is always equal to the number of episodes minus 1. 
There is substantial variation across countries and educational levels, but not across gender. Looking at the average duration of education within the first five years upon leaving school, one can see that young people in Belgium pursue some form of education for 26.2 months on average. Danish and Irish school leavers also spend more than a quarter of this period in education, pursuing, for example, university studies or further education. In Germany and the United Kingdom, only 5.5 months of the five-year period are spent in education. This is compensated for in the German case by a long average duration of apprenticeship, which reflects the existence of an institutionalised apprenticeship system: young people are in this status for nearly twenty months. Apprenticeship plays a role in Denmark as well, which is viewed as a hybrid system (OECD 1998) and where, on average, 8.4 of the 60 months are apprenticeship months. Regarding the average duration of employment within the first five years upon leaving school, the highest values can be found in the liberal countries Ireland and the United Kingdom. In these countries, people quickly enter into an employment relationship, and vocational training mostly takes place on the job. However, the fact that Irish and British school leavers are situated in employment does not say anything about the quality of their jobs. In the southern European countries Italy, Greece and Spain - unemployment is a common experience for labour market entrants, as their average duration in unemployment shows. In Italy, school leavers are in unemployment for longer than 25 months; in Greece and Spain this status adds up to 20 and 17.6 months, respectively. Denmark, Germany and Ireland have the shortest unemployment durations. Country-specific differences are also visible with respect to inactivity. For example, Greek labour market entrants are inactive 13.5 of the 60 months, whereas their Irish counterparts spend only 2.2 months in inactivity. An examination of gender differences in these aggregate measures of duration reveals only a weak correlation. Male school leavers have a slightly shorter duration in unemployment than do women, and they spend more time in apprenticeship and employment than their female counterparts do.

Although gender and country can be clearly defined as a cause in relation to labour market entry sequences, this does not hold for the level of education, because the latter changes over time depending on the character of the transition period. This is especially true for school leavers who attend university and/or take up an apprenticeship. Hence, educational level in this context means educational level at the end of the sequence, ${ }^{15}$ and therefore must be interpreted as an effect of the sequence character. With that in mind, the differences in average status duration become obvious. Labour market entrants with a tertiary level of education (ISCED 4-7) were in education on average for 20 out of 60 months, whereas those with secondary education or less (ISCED 0-2) only took part in education for 4.4 months during the five-year period. The tendency is the other way around when it comes to the duration of unemployment and inactivity: the higher the duration, the lower the level of education after five years.

15 This is partly due to data restrictions, because the variable containing educational level is only valid from the fourth wave (1998) onwards. 
The qualitative flexibility of transition sequences does not vary greatly across countries. The average number of different statuses is nearly 2.5 types within five years. Across gender and educational level there is no tendency observable, whereas country differences are apparent, even if they are small. They range from 2.2 in the United Kingdom to 3.3 in Denmark. That means that the qualitative flexibility of labour market statuses in Denmark is greater than in Great Britain.

Regarding the average number of episodes within school-to-work transitions, here, too, the differences between countries are surprisingly small. In Denmark, school leavers experience almost six episodes within the first five years after leaving school; in Belgium, Italy and Greece, only 3.7 different episodes are observable on average. There does not seem to be any clear-cut difference between ILM systems and OLM systems. Germany, with its classic OLM system, shows more status changes than the United Kingdom, which represents the classic ILM system. The same is true for Denmark and Ireland. Thus, the second hypothesis presented above must be rejected with respect to transition sequences.

Men seem to experience a slightly higher number of episodes in their school-towork transitions than do women; educational level, on the other hand, does not have a systematic effect on the number of episodes. The lower number of episodes of the middle ISCED level could be caused by those school leavers in countries with an institutionalised vocational training system, which tends to structure the coordination process between the educational system and the labour market, though this is not reflected on the country level. The reason for this discrepancy is that the country averages of course include all transition sequences occurring in the country. A more differentiated picture of volatility can be drawn if the number of episodes in certain status types is taken into consideration. The high number of education and employment episodes in Denmark and Ireland, together with relatively low values in unemployment, denotes that employment often is interrupted by education spells. On the other hand, high values in employment turn out to be unfavourable if they are coupled with low education values and high unemployment values, such as in the case of the United Kingdom and France.

To capture this volatility, an indicator has been constructed which shows the relation between the number of episodes in education, apprenticeship and employment, on the one hand, and unemployment and inactivity, on the other. This indicator shows a more favourable situation in Ireland, Germany and Denmark, whereas in France and in the United Kingdom the situation of labour market entrants is less favourable. Gender differences are not observable with this indicator, but there is a positive volatility with a higher level of education. Hypothesis 3 is confirmed: the high values of positive volatility in Ireland, Denmark and Germany clearly correspond to the existence of initial and/or further training systems. 
A next step for an aggregate description is to look at the monthly proportion of statuses with respect to country, gender and educational level. This also ignores the sequence character, but gives a simplified and aggregated picture of the share of school leavers in the respective labour market status and its development across the transition period.

An examination of the proportions of monthly labour market statuses shows that country differences are obvious (Figure 1). Germany stands out most clearly with its high number of apprenticeship statuses in the first three years after completion of schooling. At the same time, Germany is the only country where the share of young people who are in education, an apprenticeship or employment decreases slightly. Apprenticeship also plays a significant role in Denmark, Belgium, Ireland and, to a shorter extent, the United Kingdom. In the United Kingdom, apprenticeships are confined mostly to the first two years after leaving school, whereas they are spread over the entire period in the three other countries. Another striking fact is the heavy weight of unemployment in the southern European countries, particularly in Italy, Greece and Spain. Between $70 \%$ and $90 \%$ of young people are unemployed or inactive directly after leaving school; within the five-year period that share decreases to a level between $25 \%$ in Spain and $40 \%$ in Italy and Greece. Considerably high shares of unemployment and inactivity can be found in Belgium, France, Portugal and the United Kingdom. In all countries the share of employment increases, with the exception of Denmark, where it remains stable across the entire observation period. At the same time, Denmark is characterised by a high and stable level of education. The figures for gender and education do not provide clear correlations, and they are not shown here.

These aggregated measures give important information about the shares of single labour market statuses on the macro level, but they do not take into account transition sequences as a whole. ${ }^{16}$ At the descriptive level, sequences can be sorted by their pure order of status types. The most frequent sequence orders together with the corresponding sequence types discussed by Reinhold Sackmann and Matthias Wingens (2003) are shown in Table 2 (episode lengths are neglected).

Perhaps most striking at first is that the fifteen most frequent sequence types cover only a third of all the sequences in the analysis. This might be reassuring when one bears in mind the maximum possible number of combinations, but it is still hardly feasible even to handle these fifteen types (and discard all the others). However, if one follows the sequence typology of Sackmann and Wingens

16 Coloured graphical displays of all individual sequences by country, gender and educational level - so-called "sequence index plots" - can be downloaded from the author's Web site: http://www.wz-berlin.de/ brzinsky-fay. 
Figure 1: Monthly proportion of statuses by country

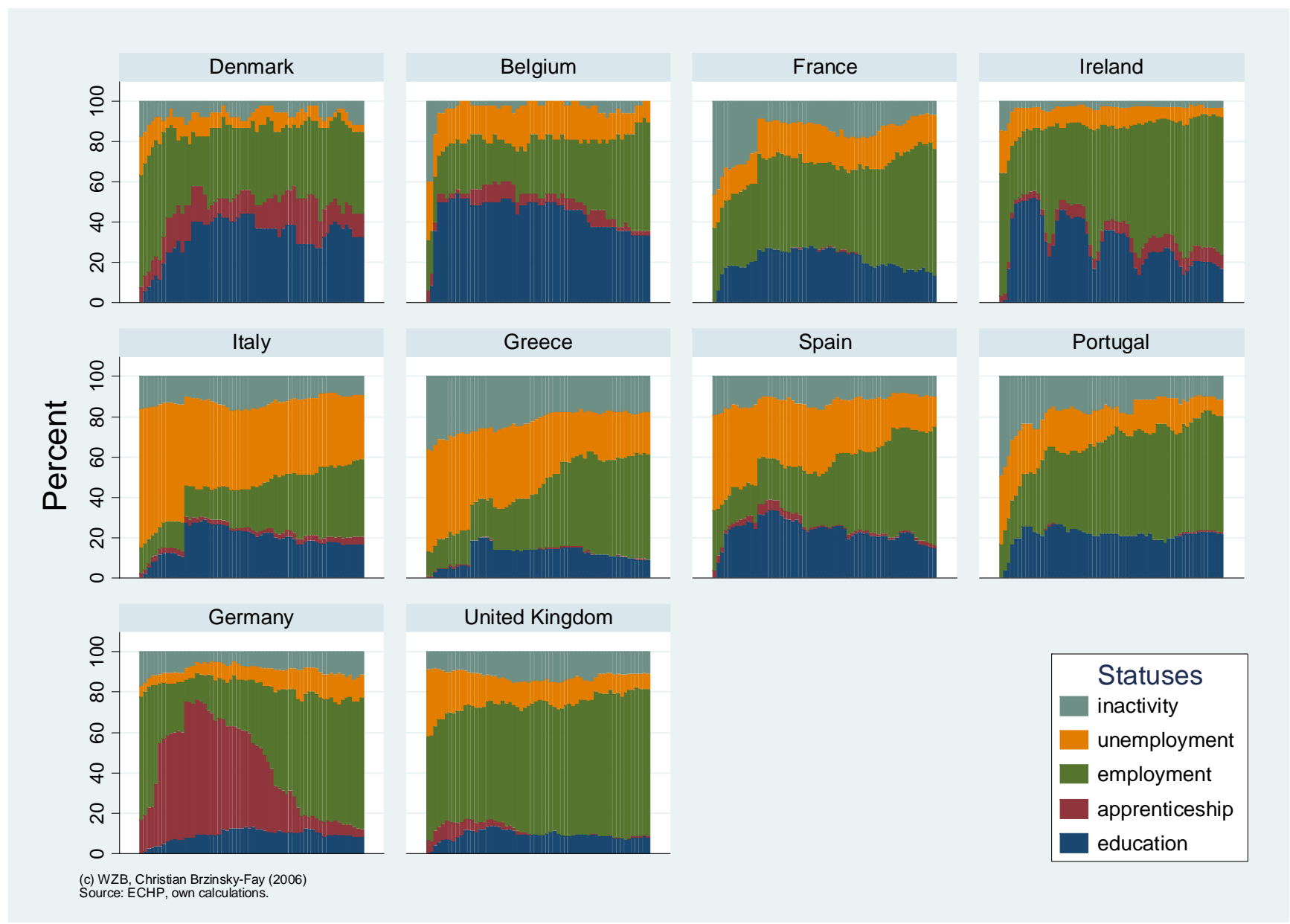


Table 2: Sequence orders and sequence types

\begin{tabular}{lc|ccc|c}
\hline \multicolumn{2}{c|}{ Sequence order } & Frequency & Percent & Cumulated & Sequence Type \\
\hline 1. & UE - EM & 95 & 5.8 & 5.8 & detour \\
2. & EM & 84 & 5.1 & 10.9 & rupture \\
3. & UE & 54 & 3.3 & 14.2 & rupture \\
4. & IN - ED & 48 & 2.9 & 17.1 & return \\
5. & UE - EM - UE - EM & 40 & 2.4 & 19.6 & detour \\
6. & EM - AP & 39 & 2.4 & 21.9 & fusion \\
7. & UE - ED & 35 & 2.1 & 24.1 & return \\
8. & IN & 32 & 2.0 & 26.0 & rupture \\
9. & EM - ED & 29 & 1.8 & 27.8 & interruption \\
10. & AP - EM & 26 & 1.6 & 29.4 & bridge \\
11. & UE - IN & 26 & 1.6 & 31.0 & change \\
12. & IN - EM & 25 & 1.5 & 32.5 & detour \\
13. & EM - UE - EM & 24 & 1.5 & 33.9 & detour \\
14. & EM - ED - EM & 23 & 1.4 & 35.3 & detour \\
15. & EM - IN - EM & 22 & 1.3 & 36.7 & detour \\
\hline
\end{tabular}

Source: ECHP, own calculations.

Note: For the sake of clarity, this table shows only the fifteen most frequent sequence orders. Altogether there are 576 different sequence orders in the data, of which 409 appear only once.

(2003), these empirical sequence orders can be classified into seven groups, ${ }^{17}$ which then transfers the empirical school-to-work transitions to an abstract level.

The most frequent sequence order begins with unemployment directly upon leaving school and leads to employment. Like the fifth and the twelfth to the fifteenth orders, these statuses lead to employment after the individual has experienced other labour market statuses: they reflect the search and/or coordination process on the youth labour market. The corresponding sequence type therefore is the 'detour', which amounts to 229 cases and is the most frequent sequence type. It can be assumed that less coordinated transition regimes have a relatively high share of this type. Those sequence orders that contain only one single labour market status are called 'rupture' and constitute the second largest sequence type. Persons with these sequences are either excluded from or included in the labour market by means of one single decision. This sequence order cannot be assessed as positive or negative, because it only reflects the strict determination of a transition. The sequence type 'return' denotes those sequences that end with education but have an episode of unemployment or inactivity in between. They

17 The typology of Sackmann and Wingens contains the types 'rupture', 'interruption', 'change', 'bridge', 'return' and 'fusion'. The seventh sequence type ('detour') has been introduced by the author in order to capture transitions that ultimately lead to employment via other statuses. 
can be viewed as an activation or bridging strategy to avoid a longer unemployment period. This type must be distinguished from 'interruption', whereby the return to education follows an episode of employment. In this case, the motivation most probably is to extend one's qualifications. Only fewer than $2 \%$ of all sequences belong to this type. There are two types of sequences that are related to apprenticeship in particular. The first one, 'bridge', describes exactly what the dual system is made for - namely, the combination of school and work as a bridge from the educational system to the labour market. The pure type can be found in only 26 sequences, of which most presumably can be found in Germany. The second one, 'fusion', has a sequence order mirroring the 'bridge' type: it leads to an apprenticeship after the experience of employment. This type is quite untypical for an institutionalised vocational training system and may be found in countries where apprenticeships have a programme-like character, such as the United Kingdom (Hillmert 2002: 680). The last sequence type discussed by Sackmann and Wingens is called 'change'. It simply describes a transition that ends up in an undefined status, such as unemployment or inactivity, and that therefore has no visible strategy or ultimate goal.

This classification system can introduce some theoretical value, but it is not feasible to group all of the occurring sequences, because even sequences that appear only once have to be classified 'by hand'. Moreover, it disregards the time dimension, which contains important information about sequences and therefore should be considered. In order to take the temporal dimension into account, it is necessary to reduce the overall complexity of empirical sequences by putting similar sequences into groups that are as distinct as possible from each other. This task is performed in the following sub-section through the use of cluster analysis.

\subsection{Clusters of Labour Market Entry Sequences}

The cluster analysis proceeded with only the second of two steps: the first step the calculation of a dissimilarity measure - was replaced by the optimal matching algorithm. For the second step - the fusion of groups - the classic Ward linkage algorithm was used. When using a hierarchical fusion algorithm, one has to make a decision on the crucial question of the appropriate number of clusters. For contextual and practical reasons, a seven-cluster solution was chosen. ${ }^{18}$ General characteristics of the clusters are shown in Table 3.

18 There is a number of coefficients that indicates the optimal cluster solution. In this case, the Calinski-Harabasz coefficient recommends a three-cluster solution, whereas the Duda-Hart test statistic allows for two interpretations - either a five- or a seven-cluster solution. After checking for all solutions from three to ten clusters, the decision was driven by the existence of analytically meaningful groups. Another argument for the seven-cluster solution is that it enables one to gain groups with a sufficient number of cases. The dendrogram of the cluster analysis can be downloaded from the author's Web site: http://www.wz-berlin.de/ brzinsky-fay. 
The 200 sequences of the first cluster are characterised by the status education, which on average amounts to 49.5 months within the first five years of leaving school. The volatility of this cluster is relatively high. The second cluster created by the algorithm consists mainly of education and employment months and has on average 5.8 episodes, which is the highest value in this category. At the same time, sequences in this cluster consist of 3.1 different statuses on average, and the volatility is on a relatively high level, similar to that for Cluster 1 . Unemployment and inactivity constitute the most important statuses of Cluster 3 and Cluster 4 , respectively; the third cluster contains slightly more education, apprenticeship and employment months. Both clusters have the lowest volatility values. Cluster 5, which is pieced together, is composed of 36.7 months of employment and fairly average shares of unemployment (9.6 months) and inactivity (7.0 months). With 443 observations, this cluster is the largest one and has low volatility. The sixth cluster is the most concentrated one: the mean duration of employment adds up to 56.7 months. As a result, in this cluster the average figures for different statuses and for episodes are the smallest, but there is moderate volatility. The last cluster is the smallest one, containing 84 observations, and includes, on average, 35.1 months of apprenticeship and 15.3 months of employment. It exhibits the highest volatility, with a value of 3.2. Table 3 provides information about the proportion of clusters for each status, ignoring the temporal

Table 3: General characteristics of clusters

\begin{tabular}{|c|c|c|c|c|c|c|c|c|}
\hline & & \multicolumn{7}{|c|}{ Cluster } \\
\hline & & 1 & 2 & 3 & 4 & 5 & 6 & 7 \\
\hline \multirow{5}{*}{ Average duration in... } & education & 49.5 & 28.4 & 3.9 & 2.6 & 2.2 & 0.4 & 3.6 \\
\hline & apprenticeship & 0.5 & 1.0 & 1.2 & 0.2 & 4.5 & 0.3 & 35.1 \\
\hline & employment & 4.1 & 19.7 & 8.3 & 4.0 & 36.7 & 56.7 & 15.3 \\
\hline & unemployment & 2.3 & 6.0 & 40.6 & 5.4 & 9.6 & 2.2 & 4.2 \\
\hline & inactivity & 3.6 & 5.0 & 5.9 & 47.8 & 7.0 & 0.4 & 1.8 \\
\hline \multicolumn{2}{|c|}{ Average number of different statuses } & 2.5 & 3.1 & 2.5 & 2.0 & 2.8 & 1.8 & 2.9 \\
\hline \multicolumn{2}{|c|}{ Average number of episodes } & 3.9 & 5.8 & 4.4 & 3.0 & 4.7 & 2.5 & 4.1 \\
\hline \multirow{5}{*}{$\begin{array}{l}\text { Average number of } \\
\text { episodes in... }\end{array}$} & education & 1.7 & 1.8 & 0.4 & 0.3 & 0.3 & 0.1 & 0.3 \\
\hline & apprenticeship & 0.1 & 0.1 & 0.2 & 0 & 0.4 & 0.1 & 1.2 \\
\hline & employment & 1.1 & 2.1 & 1.2 & 0.5 & 2.1 & 1.5 & 1.7 \\
\hline & unemployment & 0.4 & 0.9 & 2.1 & 0.7 & 1.3 & 0.7 & 0.7 \\
\hline & inactivity & 0.7 & 0.8 & 0.6 & 1.4 & 0.7 & 0.1 & 0.3 \\
\hline \multicolumn{2}{|l|}{ Volatility indicator } & 2.6 & 2.4 & 0.7 & 0.4 & 1.4 & 2.1 & 3.2 \\
\hline \multicolumn{2}{|l|}{$\mathrm{N}$} & 200 & 199 & 384 & 100 & 443 & 223 & 84 \\
\hline
\end{tabular}

Source: ECHP, own calculations. 
dimension and sequence character. To include time at first and keep as much lucidity as possible, the monthly proportion of statuses in the respective clusters should be examined (Figure 2). ${ }^{19}$

In the first cluster with its focus on education, at the beginning of the observation period around $40 \%$ of school leavers are employed, $40 \%$ are inactive and $20 \%$ are unemployed. In the first year these numbers decrease sharply, and the share of education remains on a very high level throughout the entire five years. According to the sequence typology of Sackmann and Wingens (2003), this cluster primarily is built on 'return'-type sequences and therefore can be called the 'return' cluster. Reasons for returning to education can be escape from unemployment (Scherer 2001: 135) or so-called waiting loops, whereby young people take up work only as an interlude between general and higher education.

The second cluster also includes a good share of education, as well as a considerable share of employment. Because education is concentrated at the beginning and employment at the end of the observation period, it can be assumed that education has a linking function in these sequences. Thus, this cluster should be called the 'link' cluster. Unemployment is the primary labour market status of the third cluster, and it is spread more or less equally across the entire five years. That is why this cluster can rightly be called the 'failure' cluster. Around $15 \%$ of all school leavers in this cluster are unemployed for the entire period under observation. The only difference between the 'failure' cluster and the fourth cluster is that in the latter inactivity is the most important status; moreover, $30 \%$ of all young people in this cluster are inactive for the entire five years. Because the majority of employment statuses are located at the beginning, and because inactive people are by definition outside the labour market, this cluster can be labelled the 'dropout' cluster. The 'failure' and the 'dropout' cluster correspond to 'rupture' and 'change' in Sackmann and Wingens's typology. Besides the 'link' cluster, the fifth cluster is the most manifold one. It contains a high share of employment, but also considerable shares of unemployment, apprenticeship and inactivity. Most of the sequences lead to employment and thus to integration into the labour market. Because the average number of different statuses as well as episodes is relatively high, it can be assumed that many of the sequences comply with the detour sequence type. This cluster is thus referred to as the 'detour' cluster. The most successful school-to-work transitions are surely located in the sixth cluster, where only a very small share of statuses other than employment appears. And because these can be found at the very beginning, this cluster can be called the 'express' cluster. Finally, the last cluster, which consists largely of apprenticeship and employment, reflects perfectly what Sackmann and Wingens describe as the 'bridge' type, by which means the aspired status of employment is reached from the starting point of education via a hybrid status. Consequently, this status is called the 'bridge' cluster.

19 It should be pointed out that this figure does not show individuals' sequences, but only the share of monthly statuses. 
To examine the sequential character of the transition process, it is necessary to look at the graphical display of individual sequences by cluster (Figure 3). This step verifies the conclusions drawn from the monthly proportions and gives an impression of the complexity of transition sequences. Those from the 'return' cluster start with an episode of employment, unemployment or inactivity lasting roughly one year, and after that they return to education for the rest of the observation period. There are some sporadic interruptions, which in some cases can be interpreted as summer employment of students, but a major change of status rarely occurs. The linking function of education statuses in the 'link' cluster becomes visible, too: the education periods clearly become shorter, so that the majority of school leavers end up in employment after five years. The sequence index plot of the 'failure' cluster shows the predominance of unemployment that is conspicuously spread across the entire period. Only a very small share of the people in this cluster are employed at the end of the transition period. The same is true for the 'dropout' cluster. The 'detour' cluster indeed shows a great deal of fuzziness in transition sequences. Many school leavers need to experience various labour market statuses before they gain employment, perhaps because of search processes. Sequences from the 'express' cluster rarely start with unemployment and are seldom interrupted by any other status, so that they nearly always end up in employment. Finally, the 'bridge' cluster shows the bridging function of apprenticeships, but also reveals that it is not always the case that young people are employed after taking part in an apprenticeship.

Table 4: Transition characteristics of sequence clusters

\begin{tabular}{l|ccccccc}
\hline & Return & Link & Failure & Dropout & Detour & Express & Bridge \\
\hline Volatility & + & + & - & - & - & + & ++ \\
Integrative capability & $(+/-)$ & + & - & - & ++ & ++ & + \\
Highrisk character & - & + & + & ++ & ++ & - & - \\
\hline
\end{tabular}

Source: ECHP, own calculations.

On the basis of the above descriptive information about composition, monthly proportion and sequence index, these clusters can be classified according to the properties of volatility, integrative capability and degree of risk (Table 4). The transitions of the 'return' cluster have medium volatility but do not have a high-risk character. It is difficult to assess the integrative capability of this type, because it must be assumed that integration into the labour market will occur after the observation period ends. The sequences from the 'link' cluster have considerable volatility and a moderate-risk character, while being integrative at the same time. This circumstance is only seemingly contradictory, because this cluster includes mostly transitions between (further) education and other labour market statuses, 
Figure 2: Monthly proportion of statuses by cluster

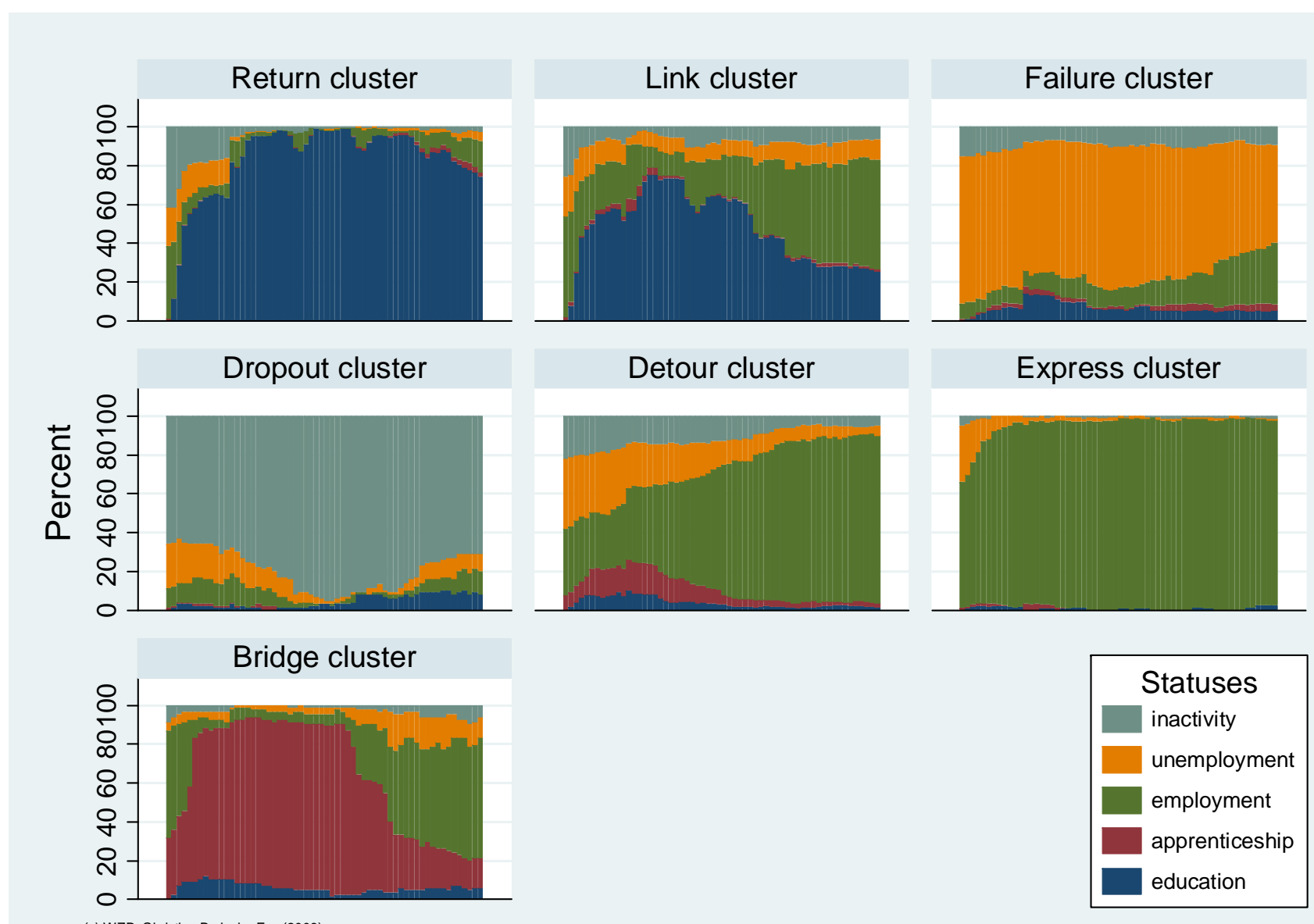

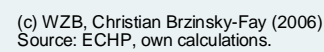


Figure 3: Sequence index plots by cluster

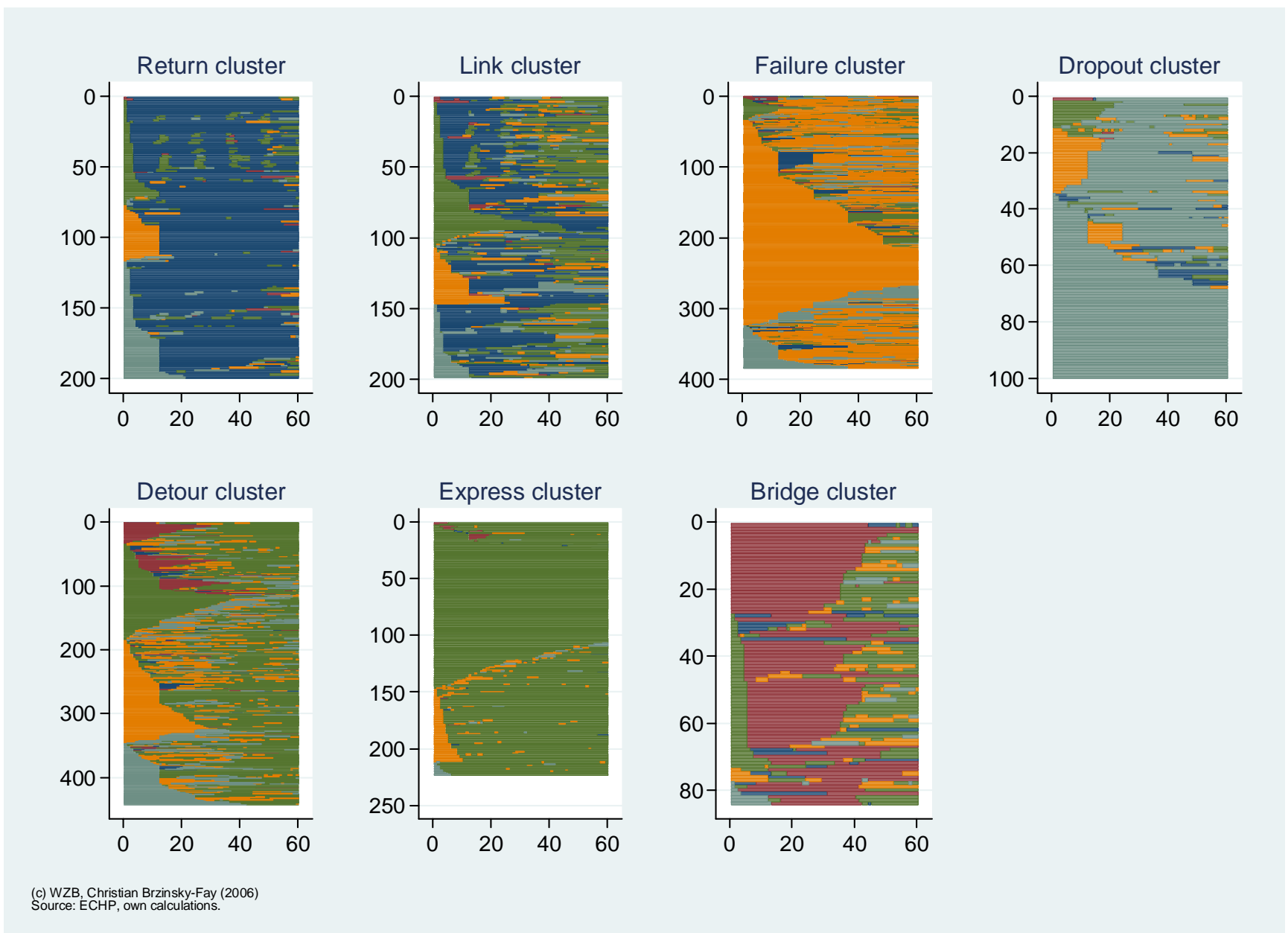


primarily employment. The transition sequences of the 'failure' and the 'dropout' types are not integrative at all and have a high-risk character, which is more evident in the 'dropout' category. The volatility of both is considerably low. The two most integrative sequence types are 'detour' and 'express', though the 'express' sequences are more volatile and far less risky than the 'detour' sequences. The 'bridge' cluster has high volatility and a moderate integrative capability, and does not exhibit much risk.

To summarise, there are distinct types of transition sequences that show explicit differences. The final question of whether or not these clusters are countryspecific will be examined in the following sub-section.

\subsection{Distribution of Sequence Types across Countries}

As Figure 4 shows, the frequencies of the clusters we have found vary substantially across countries. With the exception of the 'bridge' and the 'dropout' clusters, all remaining clusters appear in all countries. Therefore, the first hypothesis seems to be confirmed to some extent. Transition sequences from the 'return' and the 'link' clusters appear in particular in Belgium, Ireland and Denmark, where around $50 \%$ of all school leavers mainly are in education in the transition period. Though in Belgium this proportion is the largest, it includes first and foremost the 'return' cluster, because most of the education periods are not finished after five years. However, in Ireland and Denmark, sequences with a linking character amount to approximately $25 \%$ of all sequences in the respective country. The 'failure' and the 'dropout' clusters show up most concisely in the southern European countries Spain, Italy and Greece and - to a lesser extent - in Portugal, France and the United Kingdom. In Italy and Greece, about half of all transition sequences belong to these two clusters; in Spain it is only 38\%. The French, Portuguese and British transition sequences of the 'failure' and the 'dropout' clusters add up to nearly $25 \%$, whereas only in France is the 'failure' cluster clearly larger than the 'dropout' cluster. The 'dropout' cluster is not evident in Denmark and Belgium, but sequences of the 'failure' type exist in every country.

The 'detour' cluster plays a remarkable role in every country, and thus can be viewed as the most universal form of labour market entry across Western Europe. Compared to the variation of other clusters, its variation is moderate and ranges from around $15 \%$ in Belgium to $37 \%$ in Denmark. In contrast, the 'express' cluster is predominant in the liberal countries - the United Kingdom and Ireland but in Portugal, Belgium and France, too, a relatively high share of school leavers experiences transition sequences that quickly result in employment. With around $39 \%$ of all sequences belonging to this cluster, it can be viewed as typical for the United Kingdom. The 'bridge' cluster, which mostly is composed of sequences containing apprenticeship statuses, is typical for Germany, where it is institutionalised in the dual system. 
Figure 4: Appearance of clusters in countries
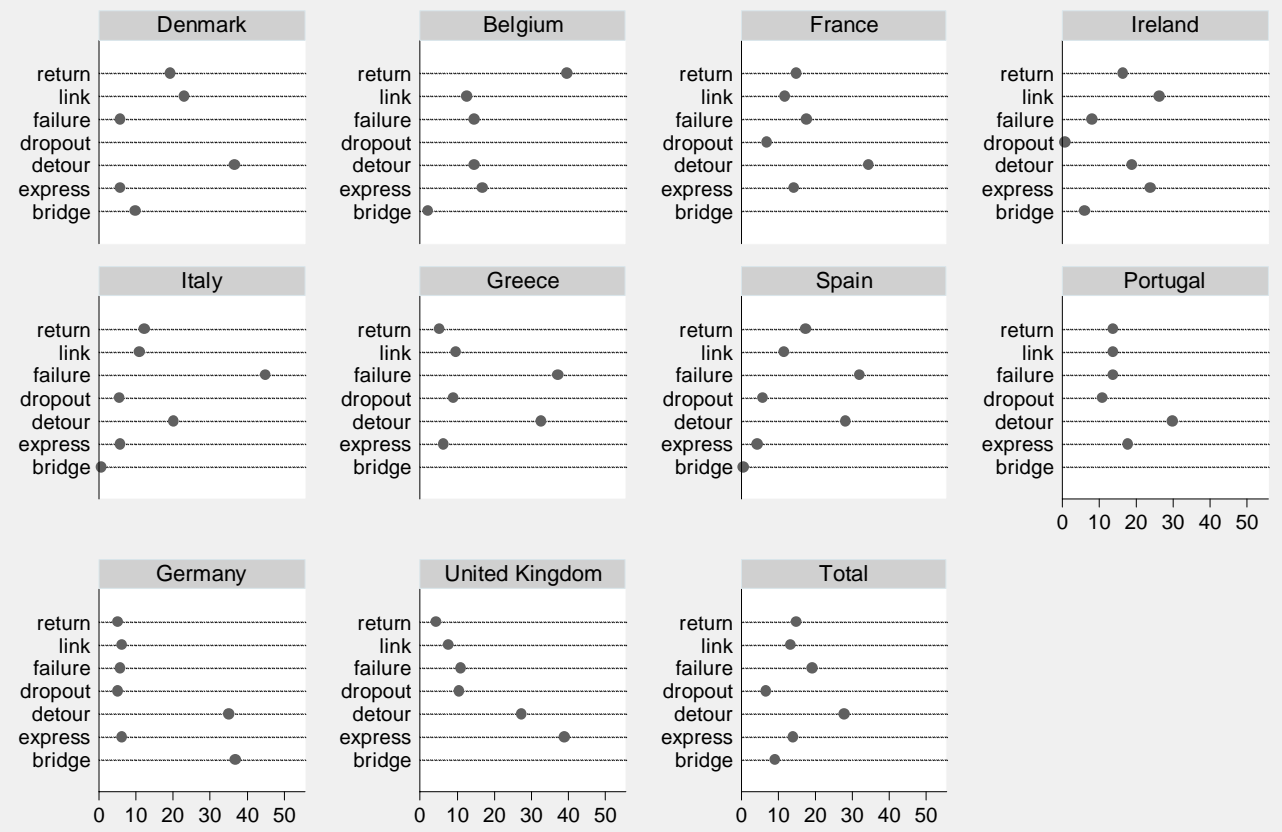

Percent

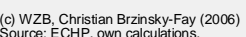

Figure 5: Integrative capability and unemployment by country

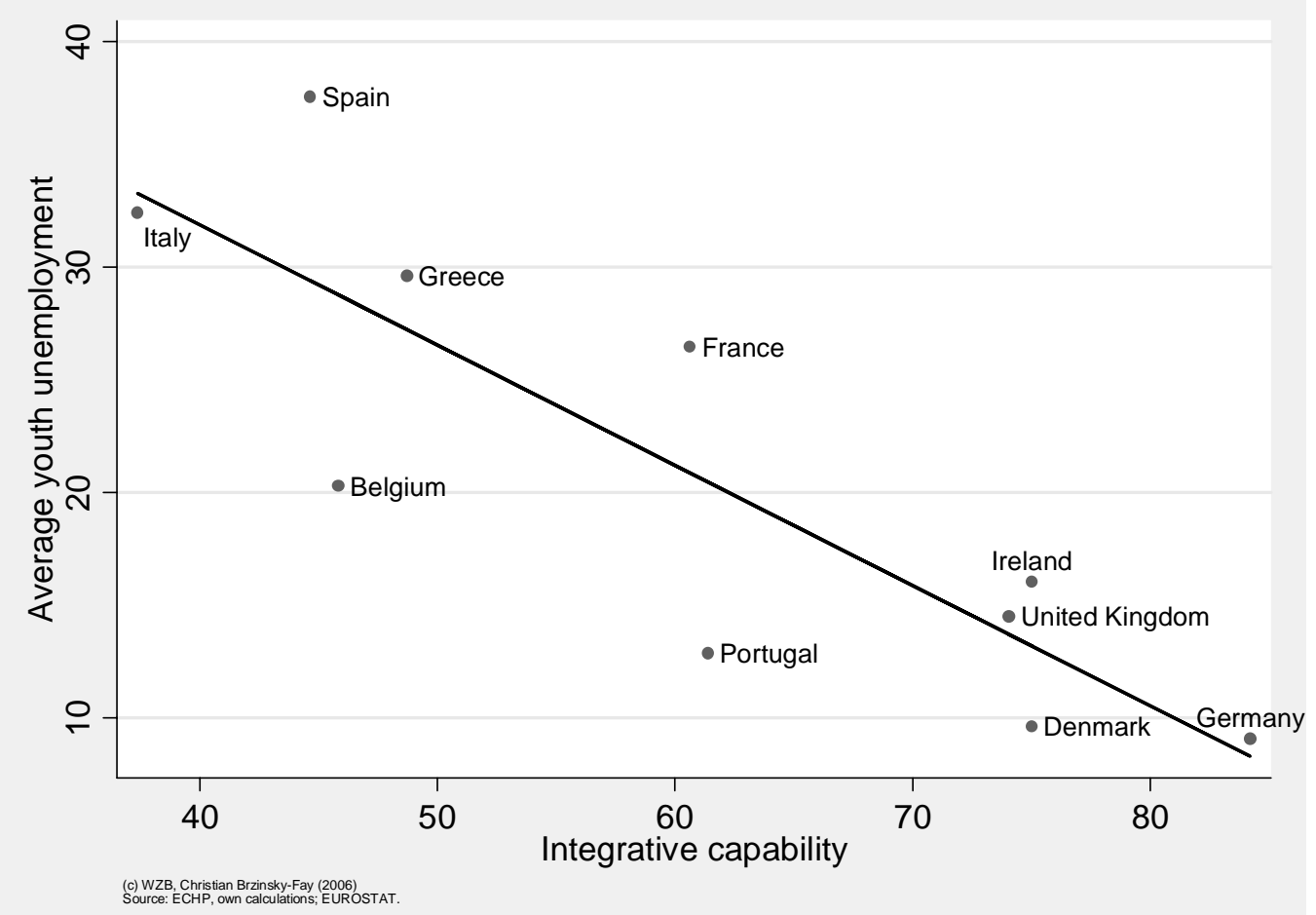


Depending on the characteristics of the sequence cluster, the quality of labour market integration within different countries and their transition regimes can now be assessed. For this purpose, the integrative capability and the share of highrisk transition types across countries are taken as indicators. Of the seven clusters, only the 'link', 'detour', 'express' and 'bridge' clusters can be regarded as integrative transition types. The share of integrative transition sequences together with the average unemployment rate is shown in Figure 5. It is not too surprising that countries with a high integrative capability have a low average youth unemployment rate. School-to-work transitions are most integrative in Germany, with around $85 \%$. In Ireland, Denmark and the United Kingdom, around three-fourths of all transition sequences have this property. In the southern European countries (with the exception of Portugal) and Belgium, fewer than $50 \%$ of young people experience integrative transition sequences. Portugal and France constitute a median group with around $60 \%$ of favourable sequences. The fourth hypothesis is thus confirmed, for the integrative capability is high in Germany and Denmark, where the transition process is considered to be coordinated, as well as in the United Kingdom and Ireland, where the temporal dimension of the integration process is emphasised. Whereas the unemployment rate reflects the overall situation in a country, transition sequences can be used to design policies for vulnerable groups, that is, for groups that need to follow a particular path into the labour market.

Figure 6: Share of high-risk sequences and average youth unemployment

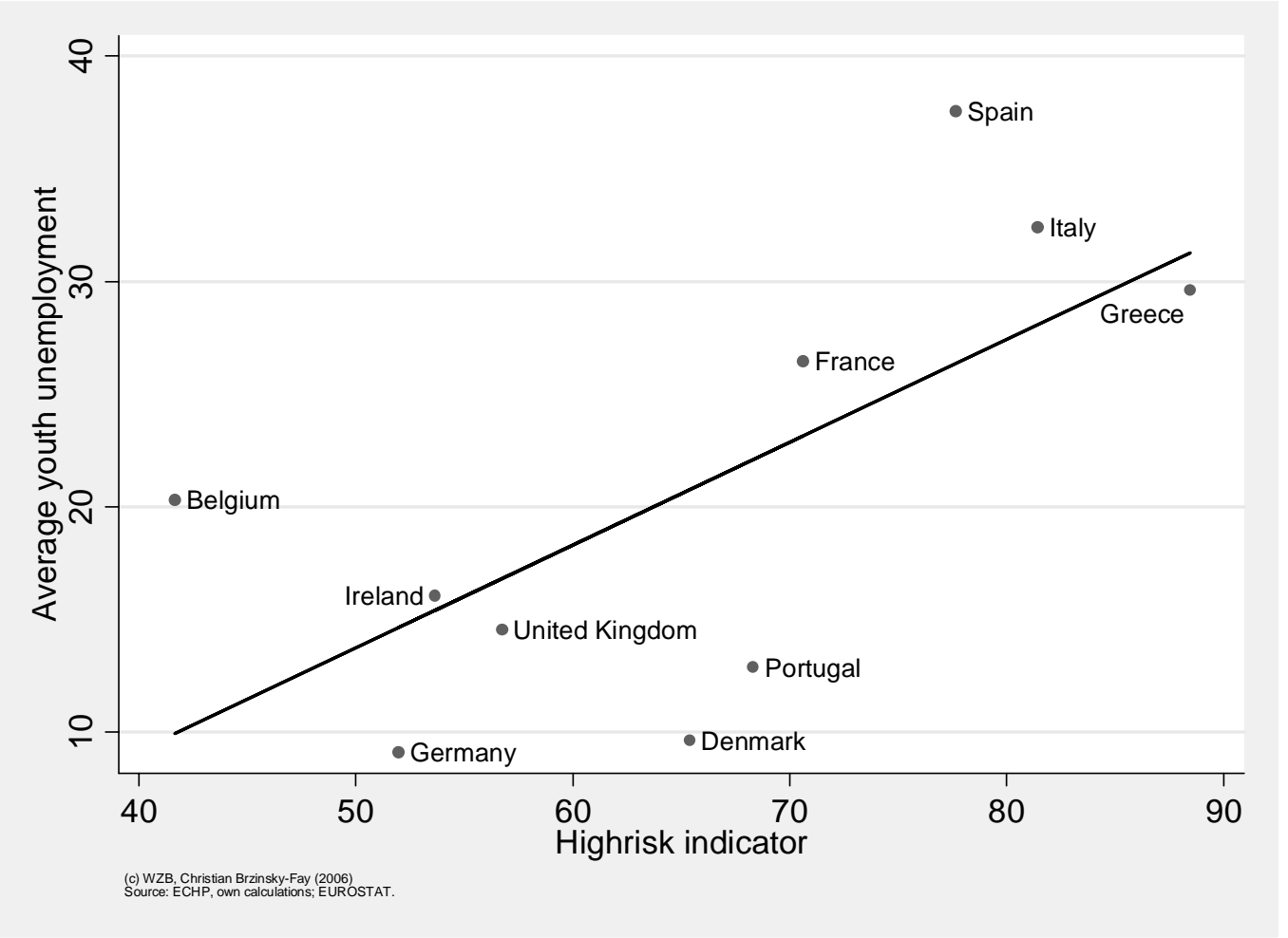


The share of high-risk sequences in the European countries varies from $40 \%$ in Belgium to nearly $90 \%$ in Greece. The southern European countries form a group with the highest share of high-risk sequences; Belgium, Germany, Ireland and the United Kingdom have relatively low values. The correlation between the share of high-risk sequences and the average youth unemployment rate is not as clear as in the case of integrative capability, but the direction is manifest. Regarding the fifth hypothesis, it is not clear that countries with a lower degree of coordination, such as the United Kingdom, Ireland and the southern European countries, have a higher share of high-risk transition sequences. This situation is true only for Spain, Italy and Greece, but not for Ireland and the United Kingdom. In this context, Denmark is an interesting case, because it has a remarkable share of highrisk transition sequences but at the same time one of the lowest unemployment rates. A risky transition is not inevitably connected with real unemployment, especially if it is accompanied by training.

\section{Conclusions and Perspectives}

To analyse school-to-work transitions on a comparative basis, the sequential character of labour market statuses must be taken into account; by this means, valuable information about country- or group-specific transitions can be obtained, which can be used to develop adequate policies. This approach requires the use of explorative methods, because the vast number of theoretically possible sequences makes it infeasible to handle them as unique cases. The optimal matching algorithm can calculate a dissimilarity measure that takes into account the sequential character of the five-year period of labour market statuses following departure from schooling. The Ward linkage algorithm in turn groups the sequences into coherent clusters on the basis of sequence differences.

The cluster analysis performed on dissimilarity measures of the OM algorithm suggested seven clusters of transition sequences, which are described according to their characteristics as 'return', 'link', 'failure', 'dropout', 'detour', 'express' or 'bridge' clusters. The existence and frequency of these clusters across countries varies widely, for they reflect different institutional configurations and their respective policies, which in turn shape different kinds of transition sequences. It is remarkable that not every sequence type appears in every country: the 'bridge' cluster does not exist in France, Greece, Portugal or the United Kingdom, and the 'dropout' cluster cannot be observed in Denmark or Belgium. The most countryspecific clusters are the 'failure' cluster for Italy, Greece and Spain; the 'express' cluster for the United Kingdom; the 'return' cluster for Belgium; the 'link' cluster for Denmark and Ireland; and the 'bridge' cluster for Germany. The 'dropout' and the 'detour' clusters are not specific for one or more countries. The ILM/OLM dichotomy and the typology of welfare regimes are able to explain only in part the appearance of clusters in the respective countries; both therefore lose their ex- 
planatory power with respect to transition sequences. Indeed, Germany, as the only explicit OLM system analysed here, clearly differs from other countries because of its dual system and the resulting high share of apprenticeships; still, the appearance of other sequence types in ILM systems cannot be explained properly. Only the number of labour market status changes is in line with this dichotomy. It is somewhat problematic to apply Esping-Andersen's typology of welfare regimes to these data, because the Scandinavian type is represented by Denmark only. The two liberal regime types, with their high proportion of 'express' sequences, and the southern European countries (excluding Portugal), with their high share of 'failure' sequences, show slight similarities, but the conservative regimes are highly diverse.

The distribution of the clusters across countries does not offer sufficient information about the overall quality of transition regimes. Three indicators served as auxiliary means in an attempt to approximate this question. First, the volatility indicator attempts to capture episode changes and to differentiate between favourable and unfavourable ones. According to this indicator, Ireland, Germany and Denmark can be considered to have positive volatility in relation to other countries. In parallel, these countries have well-established initial and/or further training systems. Second, the share of integrative sequences in every country is seen as an indicator of the overall quality of coordination of school-to-work transitions. Good performances are found primarily in Germany, but also in Ireland, Denmark and the United Kingdom. In Denmark and Germany, the coordination process is considered to be structured; in the United Kingdom, the temporal dimension of the integration process is emphasised. The third indicator pertains to the share of high-risk sequences in the countries under consideration. The highest values are found in Greece, Italy and Spain, whereas Belgium, Germany, Ireland and the United Kingdom show low values. Thus, there is no correlation between the degree of coordination and the risky character of transition sequences.

Despite all of the evidence that can be obtained by examining transition sequences, there are some serious restrictions due to data quality. First of all, combined statuses are not yet available, neither from the ECHP nor from any other comparative dataset. With the exception of apprenticeships - which can be interpreted as a hybrid status composed of employment and education - no such labour market status can be identified within the monthly calendar data. Furthermore, there is a demand for longer time series and an increased number of cases, which will enable a deeper analysis of transition sequences.

The country differences show that the path taken by school leavers into working life varies a great deal between countries, even when these paths are examined on an aggregate level. National policies that aim to facilitate the labour market integration of young people must, of course, take national peculiarities into consideration. From a European perspective, it seems impossible to implement policies that are suitable for each country's situation. This is true not only for insti- 
tutional differences but also for their empirical outcomes. Against this background, European initiatives for tackling youth unemployment must confine themselves to soft law measures such as the open method of coordination. It can, however, be useful to create policies on the European level that are targeted at groups with specific kinds of transition sequences and that can be adopted across national borders.

For the purpose of deeper examination of the quality of school-to-work transitions, it would be useful to take a closer look at the social characteristics of people in respective clusters. Thus, future applications of the sequence typology could be, for example, to include the cluster affiliation in confirmatory models in order to study the causes of particular sequence types, on the one hand, and the effects of certain transition sequences on income, participation in further training or job mobility, on the other. The individual sequence types can be used for analysis on the micro level, although the number of observations may cause some troubles. Alternatively, sequence information can be used on the macro level, in terms of country shares of certain sequence types, though the causal structure then must be abandoned.

\section{References}

Abbott, Andrew (2000): Reply to Levine and Wu, in: Sociological Methods \& Research 29 (1); pp. 65-76.

Abbott, Andrew and John Forrest (1986): Optimal matching method for historical sequences, in: Journal of Interdisciplinary History 16 (3); pp. 471-494.

Abbott, Andrew and Angela Tsay (2000): Sequence Analysis and Optimal Matching Methods in Sociology, in: Sociological Methods \& Research 29 (1); pp. 3-33.

Allmendinger, Jutta (1989): Educational Systems and Labor Market Outcomes, in: European Sociological Review 5 (3); pp. 231-250.

Detzel, Patrick and Jill Rubery (2002): Employment Systems and Transitional Labour Markets: A Comparison of Youth Labour Markets in Germany, France and the UK, in: Günther Schmid and Bernard Gazier, Eds.: The Dynamics of Full Employment. Social Integration through Transitional Labour Markets. Cheltenham/Northampton: Edward Elgar; pp. 106-148.

Dijkstra, Wil and Toon Taris (1995): Measuring the Agreement Between Sequences, in: Sociological Methods \& Research 24 (2); pp. 214-231.

Esping-Andersen, Gøsta (1990): The Three Worlds of Welfare Capitalism. Cambridge: Polity Press.

--- (1999): Social Foundations of Postindustrial Economies. Oxford: Oxford University Press.

Eurostat (2002): Sample Attrition between Waves 1 and 4 in the European Community Household Panel. Luxemburg: Eurostat (Doc PAN 185/02).

Everitt, Brian S., Sabine Landau and Morven Leese (2001): Cluster Analysis. London: Arnold. 
Franz, Wolfgang, Joachim Inkmann, Winfried Pohlmeier and Volker Zimmermann (2000): Young and Out in Germany: On the Youths' Chances of Labor Market Entrance in Germany, in: David G. Blanchflower and Richard B. Freeman, Eds.: Youth Employment and Joblessness in Advanced Countries. Chicago: The University of Chicago Press; pp. 381-425.

Gangl, Markus (2002): Changing Labour Markets and Early Career Outcomes: Labour Market Entry in Europe over the Past Decade, in: Work, Employment and Society 16 (1); pp. 67-90.

--- (2003): The structure of labour market entry in Europe: a typological analysis, in: Walter Müller and Markus Gangl, Eds.: Transitions from education to work in Europe. Oxford: Oxford University Press; pp. 95-116.

Halpin, Brendan (2003): Tracks Through Time and Continuous Processes: Transitions, Sequences and Social Structure. Frontiers in Social and Economic Mobility. University of Limerick. http://www.ul.ie/sociology/pubs/wp2003-01.pdf.

Halpin, Brendan and Tak Wing Chan (1998): Class Careers as Sequences: An Optimal Matching Analysis of Work-Life Histories, in: European Sociological Review 14 (2); pp. 111-130.

Hannan, Damian F., David Raffe and Emer Smyth (1997): Cross-National Research on School to Work Transitions: An Analytical Framework. Paris: OECD.

Hillmert, Steffen (2002): Labour market integration and institutions: an Anglo-German comparison, in: Work, Employment and Society 16 (4); pp. 675-701.

Korpi, Thomas, Paul de Graaf, John Hendrickx and Richard Layte (2003): Vocational Training and Career Employment Precariousness in Great Britain, the Netherlands and Sweden, in: Acta Sociologica 46 (1); pp. 17-30.

Levine, Joel H. (2000): But What Have You Done for Us Lately? in: Sociological Methods \& Research 29 (1); pp. 34-40.

Maclndoe, Heather and Andrew Abbott (2004): Sequence Analysis and Optimal Matching Techniques for Social Science Data, in: Melissa Hardy and Alan Bryman, Eds.: Handbook of Data Analysis. London / Thousand Oaks / New Delhi: Sage Publications; pp. 387-406.

Marsden, David (1999): A Theory of Employment Systems. Micro-Foundations of Societal Diversity. Oxford: Oxford University Press.

McVicar, Duncan and Michael Anyadike-Danes (2002): Predicting successful and unsuccessful transitions from school to work by using sequence methods, in: Journal of the Royal Statistical Society 165 (2); pp. 317-334.

O'Reilly, Jacqueline, Immaculada Cebrián and Michel Lallement, Eds. (2000): WorkingTime Changes. Social Integration Through Transitional Labour Markets. Labour Markets and Employment Policy. Cheltenham / Northampton: Edward Elgar.

OECD (1998): Employment Outlook. Paris: OECD.

Peracchi, Franco (2002): The European Community Household Panel: A Review, in: Empirical Economics 27; pp. 63-90.

Pollock, Gary, Valerie Antcliff and Rob Ralphs (2002): Work orders: analysing employment histories using sequence data, in: Social Research Methodology 5 (2); pp. 90105.

Rohwer, Götz and Ulrich Pötter (2005): TDA User's Manual (February, 2005). Bochum: Ruhr-University. 
Russell, Helen and Philip O'Connell (2001): Getting a Job in Europe: The Transition from Unemployment to Work among Young People in Nine European Countries, in: Work, Employment \& Society 15 (1); pp. 1-24.

Ryan, Paul (1999): The School-to-Work Transition: Issues for Further Investigation. Paris: OECD.

Sackmann, Reinhold and Matthias Wingens (2003): From Transitions to Trajectories. Sequence Types, in: Walter R. Heinz, Ed. Social Dynamics of the Life Course. Transitions, Institutions, and Interrelations. New York: Aldine de Gruyter; pp. 93-115.

Scherer, Stefani (2001): Early Career Patterns: A Comparison of Great Britain and West Germany, in: European Sociological Review 17 (2); pp. 119-144.

--- (2005): Patterns of Labour Market Entry - Long Wait or Career Instability? An Empirical Comparison of Italy, Great Britain and West Germany, in: European Sociological Review 21 (5); pp. 427-440.

Schmid, Günther (1998): Transitional Labour Markets: A New European Employment Strategy. Berlin: Wissenschaftszentrum Berlin für Sozialforschung (WZB) (Discussion Paper FS I 98-206).

--- (2002): Towards a Theory of Transitional Labour Markets, in: Günther Schmid and Bernard Gazier, Eds.: The Dynamics of Full Employment. Social Integration Through Transitional Labour Markets. Cheltenham/Northampton: Edward Elgar; pp. 151-195.

--- (2006): Social Risk Management Through Transitional Labour Markets, in: SocioEconomic Review 4 (1); pp. 1-33.

Schmid, Günther and Klaus Schömann (2004): Managing Social Risks Through Transitional Labour Markets. Towards A European Social Model. Amsterdam: SISWO/Institute for the Social Sciences (TLM.NET Working Paper 2004-01).

Shavit, Yossi and Walter Müller, Eds. (1998): From School to Work: A Comparative Study of Educational Qualifications and Occupational Destinations. Oxford: Clarendon Press.

Wu, Lawrence L. (2000): Some Comments on "Sequence Analysis and Optimal Matching Methods in Sociology: Review and Prospect", in: Sociological Methods \& Research 29 (1); pp. 41-64. 
Books published by members of the research unit Labor Market Policy and Employment

(available from commercial retailers)

Dietmar Dathe, Günther Schmid Urbane Beschäftigungsdynamik. Berlin im Standortvergleich mit Ballungsregionen 2001

Berlin, edition sigma

$175 \mathrm{pp}$.

Mathias Eberling, Volker Hielscher, Eckart Hildebrandt, Kerstin Jürgens Prekäre Balancen. Flexible Arbeitszeiten zwischen betrieblicher Regulierung und individuellen Ansprüchen 2004

Berlin, edition sigma $279 \mathrm{pp}$.

Werner Eichhorst, Stefan Profit, Eric Thode

in collaboration with the "Benchmarking" team at the „Bündnis für Arbeit, Ausbildung und Wettbewerbsfähigkeit" Alliance: Gerhard Fels, Rolf G. Heinze, Heide Pfarr, Günther Schmid, Wolfgang Streeck Benchmarking Deutschland: Arbeitsmarkt und Beschäftigung. Bericht der Arbeitsgruppe Benchmarking und der BertelsmannStiftung 2001

Berlin/Heidelberg/New York, Springer $440 \mathrm{pp}$.

Jürgen Gabriel, Michael Neugart (eds.) Ökonomie als Grundlage politischer Entscheidungen

2001

Opladen, Leske + Budrich

$343 \mathrm{pp}$.
Silke Gülker, Christoph Hilbert, Klaus Schömann

Lernen von den Nachbarn. Qualifikationsbedarf in Ländern der OECD 2000

Bielefeld, W. Bertelsmann Verlag $126 \mathrm{pp}$.

Markus Gangl

Unemployment Dynamics in the

United States and West Germany.

Economic Restructuring, Institutions and Labor Market Processes 2003

Heidelberg, New York: Physica/Springer $300 \mathrm{pp}$.

Werner Jann, Günther Schmid (eds.) Eins zu eins? Eine Zwischenbilanz der Hartz-Reformen am Arbeitsmarkt 2004

Berlin: edition sigma

$112 \mathrm{pp}$.

Max Kaase, Günther Schmid (eds.)

Eine lernende Demokratie - 50 Jahre

Bundesrepublik Deutschland

WZB-Jahrbuch 1999

1999

Berlin, edition sigma

$586 \mathrm{pp}$.

Hartmut Kaelble, Günther Schmid (eds.)

Das europäische Sozialmodell.

Auf dem Weg zum transnationalen

Sozialstaat.

WZB-Jahrbuch 2004

2004

Berlin, edition sigma

$455 \mathrm{pp}$. 
Jaap de Koning, Hugh Mosley (eds.)

Labour Market Policy and Unem-

ployment: Impact and Process

Evaluations in Selected European

Countries

2001

Cheltenham, UK, Edward Elgar

$317 \mathrm{pp}$.

Hugh Mosley, Jacqueline O'Reilly,

Klaus Schömann (eds.)

Labour Markets, Gender and

Institutional Change. Essays in

Honour of Günther Schmid

2002

Cheltenham, UK, Edward Elgar

$382 \mathrm{pp}$.

Hugh Mosley, Holger Schütz, Günther Schmid with the collaboration of Kai-

Uwe Müller

Effizienz der Arbeitsämter: Leistungsvergleich und Reformpraxis.

Reihe „Modernisierung des öffentlichen

Sektors"

2003

Berlin, edition sigma

$179 \mathrm{pp}$.

Ralf Mytzek, Klaus Schömann (eds.)

Transparenz von Bildungsabschlüssen in Europa. Sektorale Studien zur Mobilität von Arbeitskräften

2004

Berlin, edition sigma

$198 \mathrm{pp}$.

Michael Neugart, Klaus Schömann

(eds.)

Forecasting Labour Markets in OECD

Countries. Measuring and Tackling

Mismatches

2002

Cheltenham, UK, Edward Elgar

$322 \mathrm{pp}$.
Jacqueline O'Reilly, Colette Fagan

(eds.)

Part-Time Prospects. An International

Com-parison

1998

London/New York, Routledge

$304 \mathrm{pp}$.

Jacqueline O'Reilly, Inmaculada Cebrián and Michel Lallemant (eds.)

Working-Time Changes: Social Integration Through Transitional Labour Markets

2000

Cheltenham, UK, Edward Elgar

$369 \mathrm{pp}$.

Jacqueline O'Reilly (ed.)

Regulating Working-Time Transitions

in Europe

2003

Cheltenham, UK, Edward Elgar

$325 \mathrm{pp}$.

Birgitta Rabe

Implementation von Arbeitsmarktpolitik durch Verhandlungen. Eine spieltheoretische Analyse 2000

Berlin, edition sigma

$254 \mathrm{pp}$.

Stefan Ramge, Günther Schmid (eds.)

Management of Change in der Politik? Reformstrategien am Beispiel der Arbeitsmarkt- und Beschäftigungspolitik

Ein Werkstattbericht, Gesellschaft für Programmforschung, GfP (ed.), Bd. 55 der Reihe „Schnittpunkte von Forschung und Politik",

2003

New York, München, Berlin: Waxmann $165 \mathrm{pp}$. 
Günther Schmid, Jacqueline O'Reilly,

Klaus Schömann (eds.)

International Handbook of Labour

Market Policy and Evaluation

1996

Cheltenham, UK, Edward Elgar

$954 \mathrm{pp}$.

Günther Schmid, Bernard Gazier (eds.)

The Dynamics of Full Employment.

Social Integration Through Transi-

tional Labour Markets

2002

Cheltenham, UK, Edward Elgar

$443 \mathrm{pp}$.

Günther Schmid

Wege in eine neue Vollbeschäftigung.

Übergangsarbeitsmärkte und ak-

tivierende Arbeitsmarktpolitik

2002

Frankfurt/Main, Campus

$477 \mathrm{pp}$.

Sylvia Zühlke

Beschäftigungschancen durch

berufliche Mobilität? Arbeitslosigkeit, Weiterbildung und Berufswechsel in Ostdeutschland

2000

Berlin, edition sigma,

$206 \mathrm{pp}$. 


\section{Research Unit \\ Labor Market Policy and Employment}

\section{Discussion Papers 2002}

Sophie Rouault

Multiple jobholding and pathdependent employment regimes answering the qualification and protection needs of multiple jobholders Order number: FS I 02 - 201

Sophie Rouault, Heidi Oschmiansky, Isabelle Schömann (eds.)

Reacting in time to qualification needs: Towards a cooperative implementation?

Order number: FS I 02 - 202

Michael Neugart, Donald Storrie Temporary Work Agencies and Equilibrium Unemployment Order number: FS I 02 - 203

Ruud Muffels, Ton Wilthagen, Nick van den Heuvel Labour Market Transitions and Employment Regimes: Evidence on the Flexibility-Security Nexus in Transitional Labour Markets

Order number: FS I 02 - 204

Heidi Oschmiansky

Implementation von Jobrotation im Gesundheits- und Pflegebereich - ein dänisch-deutscher Vergleich

Order number: FS I 02 - 205

Michael Neugart, Klaus Schömann Employment Outlooks: Why forecast the labour market and for whom? Order number: FS I 02-206

\section{Markus Gangl}

Welfare State Stabilization of Employment Careers: Unemployment Benefits and Job Histories in the United States and West Germany Order number: FS I 02-207
Markus Gangl

Unemployment Benefits as a Search Subsidy: New Evidence on Duration and Wage Effects of Unemployment Insurance

Order number: FS I 02-208

Hugh Mosley, Holger Schütz, Günther Schmid

Effizienzmobilisierung der Arbeitsverwaltung: Leistungsvergleich und Lernen von guten Praktiken (Benchmarking)

Order number: FS I 02-209

Ronald Schettkat

Institutions in the Economic Fitness Landscape

What Impact do Welfare State Institutions have on Economic Performance? Order number: FS I 02-210

Christoph Hilbert, Ralf Mytzek Strategische und methodische Ansatzpunkte zur Ermittlung des regionalen Qualifikationsbedarfs Order number FS I 02-211

Ronald Schettkat

Differences in US-German Time-

Allocation. Why do Americans work longer hours than Germans?

Order number FS I 02-212

Frank Oschmiansky, Bernd Reissert Förderung von Übergangsarbeitsmärkten in Berlin und Brandenburg: eine quantitative Untersuchung Order number FS I 02-213

Oliver Bruttel

Die Privatisierung der öffentlichen Arbeitsverwaltung am Beispiel Australiens Order number FS I 02-214 
As of 2003:

The Research Area "Employment, Social Structure, and Welfare State" has existed since 1 January 2003. It encompasses the research units "Labor Market Policy and Employment" and "Inequality and Social Integration" and the research group "Public Health".

\section{Research Unit Labor Market Policy and Employment}

\section{Discussion Papers 2003}

Carroll Haak

Weiterbildung in kleinen und mittleren Betrieben: Ein deutschdänischer Vergleich

Order number: SP I 2003-101

Günther Schmid

Gleichheit und Effizienz auf dem

Arbeitsmarkt: Überlegungen zum

Wandel und zur Gestaltung des

"Geschlechtervertrages"

Order number: SP I 2003-102

Holger Schütz

Controlling von Arbeitsverwaltungen

im internationalen Vergleich

Order number: SP I 2003-103

\section{Stefan Schröter}

Berufliche Weiterbildung in Großbritannien für gering qualifizierte Ar-

beitskräfte

Order number: SP I 2003-104

Magnus Lindskog

Forecasting and responding to

qualification need in Sweden

Order number: SP I 2003-105

Heidi Oschmiansky, Frank Oschmiansky Erwerbsformen im Wandel: Integration oder Ausgrenzung durch atypische Beschäftigung? Berlin und die Bundesrepublik Deutschland im Vergleich

Order number: SP I 2003-106
Katrin Vitols

Entwicklungen des Qualifikationsbedarfs in der Bankenbranche Order number: SP I 2003-107

Achim Kemmerling

Die Rolle des Wohlfahrtsstaates in der Entwicklung unterschiedlicher Diensteistungssektoren - Wohlfahrtsstaatsregime und Dienstleistungsbeschäftigung

Order number: SP I 2003-108

Thomas A. DiPrete, Dominique Goux, Eric Maurin, Amélie Quesnel-Vallée Work and Pay in Flexible and Regulated Labor Markets: A Generalized Perspective on Institutional Evolution and Inequality Trends in Europe and the U.S.

Order number: SP I 2003-109

\section{Discussion Papers 2004}

Thomas A. DiPrete, Markus Gangl Assessing Bias in the Estimation of Causal Effects: Rosenbaum Bounds on Matching Estimators and Instrumental Variables Estimation with Imperfect Instruments

Order number: SP 1 2004-101

Andrea Ziefle

Die individuellen Kosten des Erziehungsurlaubs: Eine empirische Analyse der kurz- und längerfristigen Folgen für den Karriereverlauf von Frauen

Order number: SP 1 2004-102

Günther Schmid, Silke Kull

Die Europäische Beschäftigungsstrategie. Anmerkungen zur "Methode der offenen Koordinierung"

Order number: SP 1 2004-103 
Hildegard Theobald

Entwicklung des Qualifikationsbedarfs im Gesundheitssektor: Professionalisierungsprozesse in der Physiotherapie und Dentalhygiene im europäischen Vergleich

Order number: SP 1 2004-104

Magnus Lindskog

Labour market forecasts and their use - Practices in the Scandinavian countries

Order number: SP 1 2004-105

Hildegard Theobald

Unternehmensberatung: Veränderter Qualifikationsbedarf und neue Ansätze in Ausbildung und Regulierung des Berufszugangs

Order number: SP 1 2004-106

Günther Schmid

Gewährleistungsstaat und Arbeitsmarkt. Neue Formen von Governance in der Arbeitsmarktpolitik

Order number: SP I 2004-107

Karin Schulze Buschoff

Neue Selbstständigkeit und wachsender Grenzbereich zwischen selbstständiger und abhängiger Erwerbsarbeit - europäische Trends vor dem Hintergrund sozialpolitischer und arbeitsrechtlicher Entwicklungen Order number: SP 1 2004-108

Christoph Hilbert

Performanzmessung und Anreize in der regionalen Arbeitsvermittlung: Der Schweizer Ansatz und eine Modellrechnung für Deutschland Order number: SP 1 2004-109

Günther Schmid

Soziales Risikomanagement durch Übergangsarbeitsmärkte

Order number: SP I 2004-110

Lennart Delander, Jonas Månsson, Erik Nyberg

Using the Unemployed as Temporary Employment Counsellors: Evaluation of an Initiative to Combat Long-Term Unemployment

Order number: SP I 2004-111
Discussion Papers 2005

Achim Kemmerling, Oliver Bruttel New Politics in German Labour Market Policy? The Implications of the Recent Hartz Reforms for the German Welfare State

Order number: SP I 2005-101

Kamil Zawadzki

Transitional Labour Markets in a Transitional Economy. Could They Work? The Example of Poland Order number: SP I 2005-102

Magnus Lindskog

The Swedish Social Insurance System for the Self-Employed Order number: SP I 2005-103

Rebecca Boden

The UK social security system for self-employed people

Order number: SP I 2005-104

Philip Wotschack

Household Governance and

Time Allocation - Structures and Processes of Social Control in Dutch Households

Order number: SP I 2005-105

Holger Schütz, Peter Ochs

Das Neue im Alten und das Alte im Neuen - Das Kundenzentrum der Bundesagentur für Arbeit: Die öffentliche Arbeitsvermittlung zwischen inkrementellen und strukturellen Reformen

Order number: SP I 2005-106

Carroll Haak

Künstler zwischen selbständiger und abhängiger Erwerbsarbeit Order number: SP I 2005-107 
Ralf Mytzek-Zühlke

Determinanten betrieblicher Weiterbildungsaktivität in vier europäischen Ländern.

Analysen der Mikrodaten der zweiten Europäischen Weiterbildungserhebung (CVTS2)

Order number: SP | 2005-108

Oliver Bruttel

Contracting-out and Governance

Mechanisms in the Public Employment Service

Order number: SP I 2005-109

Colette Fagan, Jacqueline O'Reilly and Brendan Halpin

Job opportunities for whom? Labour market dynamics and service sector employment growth in Germany and Britain

Order number: SP I 2005-110

Monique Aerts

The Dutch Social Insurance System for Self-Employed

Order number: SP I 2005-111

\section{Discussion Papers 2006}

Günther Schmid

Sharing Risks. On Social Risk Management and the Governance of Labour Market Transitions

Order number: SP | 2006-101

Rosie Page, Jim Hallage

Vocational Education and Training in the UK. Strategies to Overcome Skill Gaps in the Workforce

Order number: SP I 2006-102

Anton Hemerijck

Recasting Europe's Semi-Sovereign Welfare States and the Role of the EU Order number: SP I 2006-103

Paul Ryan, Howard Gospel, Paul Lewis Large Employers and Apprenticeship Training in Britain

Order number: SP I 2006-104
Lorenz Lassnigg

Approaches for the anticipation of skill needs in the perspective of "Transitional Labour Markets" - the Austrian experience

Order number: SP I 2006-105

Paula Protsch

Lebens- und Arbeitsqualität von

Selbstständigen.

Objektive Lebens- und Arbeits-

bedingungen und subjektives

Wohlbefinden einer heterogenen

Erwerbsgruppe

Order number: SP I 2006-106

Karin Schulze Buschoff

Die soziale Sicherung von selbstständig Erwerbstätigen in Deutschland

Order number: SP I 2006-107

Janine Leschke, Günther Schmid, Dorit Griga

On the Marriage of Flexibility and Security: Lessons from the Hartzreforms in Germany

Order number: SP I 2006-108

Anders Stenberg

Skill Needs and Continuing Vocational Training in Sweden

Order number: SP I 2006-109

Philip Wotschack, Rafael Wittek Negotiating Work and Household Demands.

Effects of Conflict Management Strategies in Dutch Households on the Labor Supply of Male and Female Employees Order number: SP I 2006-110

Christian Brzinsky-Fay

Lost in Transition: Labour Market Entry Sequences of School Leavers in Europe

Order number: SP I 2006-111 
Absender / Return Address:

Wissenschaftszentrum Berlin

für Sozialforschung

Presse- und Informationsreferat

Reichpietschufer 50

D-10785 Berlin-Tiergarten

Hiermit bestelle ich folgende(s)

Discussion paper(s):

Bestell-Nr. / Order no.
Please send me the following

Discussion paper(s):

Autor/in, Kurztitel / Author(s) / Title(s) in brief 